\title{
Morphological and anatomical investigation of New Caledonian graminoid Dendrobium (Orchidaceae) with the description of two new species
}

\author{
Marc PIGNAL ${ }^{1, *} \&$ Jérôme MUNZINGER ${ }^{2}$ \\ ${ }^{1}$ MNHN Paris, Département Systématique et Evolution, UMR 7205 MNHN/CNRS Origine Structure \\ et Evolution de la Biodiversité, 16 Rue Buffon, C.P. 39, 75231 Paris cedex 05, France. \\ ${ }^{2}$ AMAP, Université Montpellier, IRD, CIRAD, CNRS, INRAE, Montpellier, France. \\ ${ }^{*}$ Corresponding author: marc.pignal@mnhn.fr \\ ${ }^{2}$ Email: jerome.munzinger@ird.fr
}

\begin{abstract}
Morphological characters support the description of two new species of Orchidaceae from New Caledonia: Dendrobium butinii M.Pignal \& Munzinger sp. nov. and Dendrobium letocartiorum Munzinger \& M.Pignal sp. nov. The lectotypes of Dendrobium camaridiorum Rchb.f. and D. crassifolium Schltr. are designated here. A leaf anatomical study was conducted and provided useful characters to distinguish the five New Caledonian graminoid Dendrobiineae species. Two identification tools are provided: an anatomical key for sterile material of grass-like Dendrobiineae and a morphological key for the New Caledonian graminoid Dendrobium. We propose preliminary conservation assessments with IUCN criteria for the new taxa.
\end{abstract}

Keywords. Orchidaceae, Grastidium, Dendrobium, Biloba, New Caledonia, taxonomy.

Pignal M. \& Munzinger J. 2020. Morphological and anatomical investigation of New Caledonian graminoid Dendrobium (Orchidaceae) with the description of two new species. European Journal of Taxonomy 633: 1-26. https://doi.org/10.5852/ejt.2020.633

\section{Introduction}

The New Caledonian flora is remarkable, both for its endemism, estimated at ca 75\% (Morat et al. 2012), and for the presence of numerous primitive angiosperm groups (Lowry II 1998; Pouteau et al. 2015). Morat (1993) estimated that $5-10 \%$ of the flora remained undescribed, an interpretation supported by the ongoing description of one new endemic plant species on average per month (Gâteblé et al. 2018), including some in the Orchidaceae (Pignal \& Munzinger 2011; Faria 2016). Many years ago, our colleague and friend Jean-Pierre Butin (Forest Service, Northern Province) brought to our attention some potentially new species of Orchidaceae. These belong to the genus Dendrobium Sw. and are characterized by long thin stems, and narrowly elliptical leaf blades evoking the Poaceae Barnhart, that we call therefore 'graminoid' species. Two New Caledonian species were known at that time to have this strange habit: D. camaridiorum Rchb.f. and D. crassifolium Schltr. Another graminoid Dendrobium, D. unicarinatum Kores (1989: 97) is now known to occur on the island. We quickly noticed that several herbarium specimens of graminoid Dendrobium did not match these three known species, and that 
Hallé's annotations on herbarium sheets suggested two potential new species he provisionally named: Dendrobium crassifomentum Hallé in herb. and D. crassiformatum Hallé in herb. In order to clarify the taxonomy of New Caledonian graminoid Dendrobium and evaluate the status of the putative new species, we have undertaken a revision based on morphology of all material in P and NOU. As part of this study, we also examined leaf anatomy, which has provided very informative features for classifying members of Dendrobium s. lat. (Yukawa et al. 1992; Stern et al. 1994; Morris et al. 1996; Yukawa \& Uehara 1996; Carlsward et al. 1997). The main objectives were to 1) clarify the taxonomy of graminoid Dendrobium in New Caledonia; 2) provide keys for sterile and fertile material; 3) evaluate how anatomical characters provide information about the placement of these new species in the three sections: Dendrobium Sw., Grastidium (Blume) J.J.Sm. (Smith 1905a: 348) and Biloba J.J.Sm. (Smith 1905b: 67), incl. Monanthos Schltr. (Schlechter 1912: 251).

\section{Material and methods}

We examined 109 collections from LY, NOU and P. Herbarium acronyms follow Index Herbariorum (Thiers, continuously updated). In addition, we used several virtual collections: Global Plant initiative (https://plants.jstor.org/), e-ReColNat infrastructure (https://www.recolnat.org/) and Endemia association Website (http://endemia.nc/).

The anatomy of leaves of five graminoid taxa belonging to sections Grastidium and Biloba was studied. Most samples were taken from $\mathrm{P}$ and NOU herbaria, or from cultivated material available at several institutions (see Acknowledgements and Material examined). Dried leaves were rehydrated in boiling water, transversely sectioned by hand, bleached in $10 \%$ sodium hypochlorite for $5 \mathrm{~min}$, washed and mordanted with acetic acid. The sections were then stained with methylene blue in saturated aqueous solution (5 min) and with Safranin (5 min), dehydrated by 95\% alcohol and mounted with Euparal.

For the observation of small pieces of leaves using the Scanning Electron Microscope (SEM) Jeol of the 'Service Commun de Microscopie Électronique du MNHN', samples were cleaned with butanol, fixed on aluminium stubs and sputter-coated with gold.

In parallel of that work, IUCN status was evaluated by the New Caledonian Red List Authority (RLANC) and the results are reported there. Species phenology is based on both herbarium data and Christian Laudereau's precise observations.

\section{Results}

\section{Key to the graminoid species of Dendrobium in New Caledonia}

Grass-like stems. Inflorescences 1- or 2-flowered, exactly opposite the leaf blade.

1. Flowers non-resupinate. Inflorescences 1-flowered, lamina without any visible depression. Fruit sub-globose (Dendrobium sect. Biloba)

- Flowers resupinate. Inflorescences always biflorous, lamina with a visible depression, sometimes 'V'-shaped (Fig. 1R), in the lower third; fruit fusiform (Dendrobium sect. Grastidium) ................. 3

2. Stems bifaciate. Sepals $12 \times 2-4 \mathrm{~mm}$, lateral sepals triangular. Petals linear or slightly lanceolate, $11 \times$ ca $1 \mathrm{~mm}$. Lip red, carina, 3 .

D. letocartiorum Munzinger \& M.Pignal sp. nov.

- Stems cylindrical or slightly flattened. Sepals 4-4.5 × 2.4-3 mm, lateral sepals triangular-ovate. Petals ovate, asymmetrical, ca $4 \times 2 \mathrm{~mm}$, lip white, carina, 1 D. unicarinatum Kores

3. Leafy stem thick, slightly fleshy, weakly flattened; lamina of leaf wide and short, 50-70 × 9-15 mm, ovate, coriaceous, fleshy ..... D. crassifolium Schltr. 
- Leafy stem thin, terete, not fleshy; lamina of leaf narrow, 35-100 $\times 1.5-4 \mathrm{~mm}$, slender, chartaceous and not crassulescent

4. Leaf blade $45-100 \times 4-5 \mathrm{~mm}$; sepals and petals at least $30 \mathrm{~mm}$ long; adventive plantlets frequent; sepals attenuate

D. camaridiorum Rchb.f.

- Leaf blade ca 35-40 × 1.5-2 mm; sepals and petals < $10 \mathrm{~mm}$ long; adventive roots present, but plantlets absent; sepals triangular, abruptly narrowed forming an acumen ca $4 \mathrm{~mm}$ long

D. butinii M.Pignal \& Munzinger sp. nov.

\title{
Taxonomic treatment
}

\author{
Class Angiospermae Lindl \\ Subclass Magnoliidae Takht. \\ Super-Order Lilianae Takht. \\ Family Orchidaceae Juss. \\ Genus Dendrobium Sw.
}

\section{Dendrobium unicarinatum Kores}

Figs 1B, I-J, P, 2, 3H-I, 4A, 5H

Allertonia 5: 97 (Kores 1989). - Dendrobium crassiformatum Hallé ined. in herb. - Type: FIJI - Viti Levu, Mba Province, vicinity of Nandarivatu; 17 Nov. 1927; Gillespie 3841; holotype: AMES[AMES00243052].

\section{Etymology}

The epithet refers to the carina of the lip.

\section{Material examined}

NEW CALEDONIA - Province Nord • Mont Mandjelia, Pouébo; 20²3'51" S, 164³1'57" E; 21 Feb. 2016; fr.; C. Laudereau 97; NOU[NOU090363] • Cultivated in Nouméa; C. Laudereau 172; (original material data: Roches de la Ouaième; 20³8'22" S, 16451'47" E, 6 Dec. 2016); NOU[NOU090377] - Roches de la Ouaième, Hienghène; 20 38'22" S, 16451'47" E; 22 Oct. 2018; fr.; C. Laudereau 1075; NOU[NOU090364] • Ouane Batch, Pouébo; 20³0'35" S, 16443'56" E; 23 Dec. 2018; C. Laudereau 1112; NOU[NOU090365] • Mont Mandjelia Pouébo; 20²3'51" S, 164³1'57" E; 24 Dec. 2018; fr.; C. Laudereau 1156; NOU[NOU090366] - Grande-Terre, Pouébo: Mont Mandjélia; [20²4'2" S, 164³1'42" E]; alt. 750 m; 7 Jun. 1979; H.S. MacKee \& Bégaud 36986; P[P00118407] • Pouébo: Mont Mandjélia; [20²4'2" S, 164³1'42" E]; alt. 750 m; humid forest, schists, 26 Jan. 1980; H.S. MacKee 37759 \& Bégaud; P[P00118408] • Roches de la Ouaième, on the crest; [20³8'17" S,16452'0" E]; alt. 765 m; 4 Nov. 2011; fr.; J. Munzinger 6162, V. Hequet, A. Vandrot, Ph. Birnbaum \& I. Pounds; NOU[NOU063339] - Cascade La Guen; 20³7'0" S, 16446'53" E; humid forest; st.; 21 Nov. 2010; J. Munzinger 6401, P. Lowry, M. Callmander, H. Vandrot, T. \& M. Teimpouene; NOU[NOU063581].

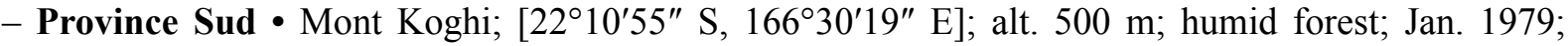
H.S. MacKee 43003 \& Labrissière; P[P00118409] • Mont Pembai; [2134'47" S, 16549'59" E]; alt. 700 m; humid forest, schists; 31 May 1990; H.S. MacKee 44925; P[P00124752, P00124753].

\section{Description}

Herb, epiphytic, erect. Roots whitish, ca 1-2 mm wide, at the base of the plant (axillary roots lacking). Stem erect, to $50 \mathrm{~cm}$ long, terete or slightly flattened, covered by the sheath of the oldest leaves, blades remaining only in the upper third of the adult stem. Internodes $25 \mathrm{~mm}$ long at the base of the stem. Leaves 


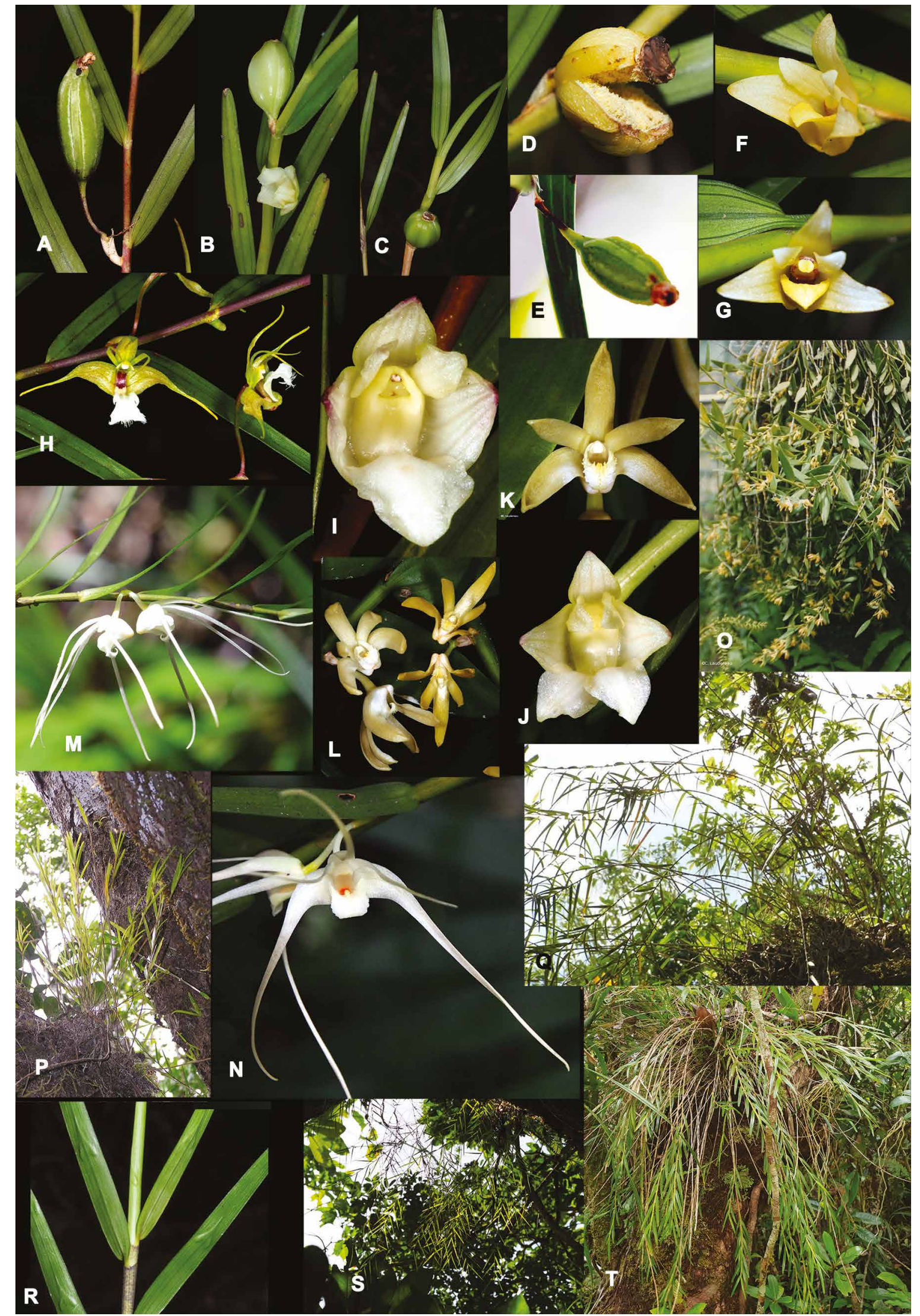

Fig. 1. (see full caption on page 5) 


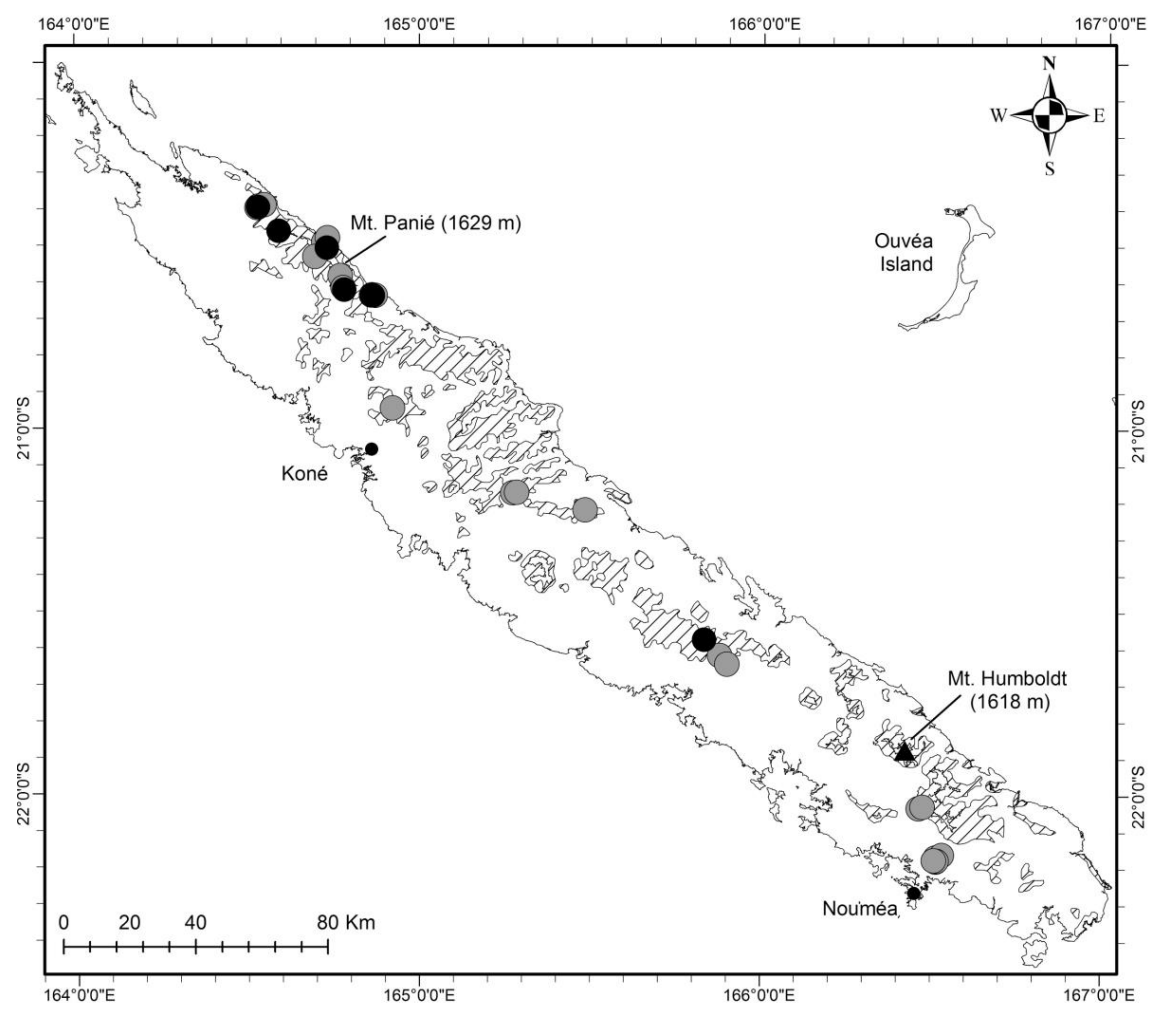

Fig. 2. Distribution of D. unicarinatum Kores in New Caledonia, based on herbarium specimens ( and field observations $(\bigcirc)$.

Fig. 1. A-E. Fruits. A. D. butinii M.Pignal \& Munzinger sp. nov., loc. Colnett Mountain, Oua Ina or Wé Ina; image $n^{\circ} \mathrm{PA} 211592$. B. D. unicarinatum Kores, cult. Nouméa (original data: Mandjélia Mount or Tidiélic Mount, $780 \mathrm{~m}$ ); image ${ }^{\circ} \mathrm{PA} 118035$. C-D. D. letocartiorum Munzinger \& M.Pignal sp. nov., Mandjélia Mount or Tidiélic Mount, $780 \mathrm{~m}$; image nPA182815. D. Dehiscent fruit, cult. Nouméa (original data: mt Mandjélia or Tidiélic, $780 \mathrm{~m}$ ); image $\mathrm{n}^{\circ} \mathrm{PC} 061498$. E. D. camaridiorum Rchb.f., Col des Roussettes, Bouirou; 5 Apr. 2015; image ${ }^{\circ} \mathrm{P} 4057147$. F-N. Flowers. F-G. D. letocartiorum Munzinger \& M.Pignal sp. nov., cult. Nouméa (original data: Mandjélia Mount or Tidiélic Mount, 780 m; 6 Dec. 2014); image nPC061503. G. Cult. Nouméa; (original data: Mandjélia Mount or Tidiélic Mount, 780 m; 6 Dec. 2014); image $n^{\circ}$ PC061504. H. D. butinii M.Pignal \& Munzinger sp. nov., Colnett Mount, Ouanebatch We Ina, 300 m; 20 Jan. 2018; image $n^{\circ}$ P1211262. I-J. D. unicarinatum Kores. I. Cult. Nouméa; 15 Nov. 2015; (original data: Roches de la Ouaieme, 800 m; 23 Oct. 2015); image $\mathrm{n}^{\circ} \mathrm{PB} 157702$. J. Teratological flower, cult. Nouméa; 30 Jul. 2015; (original data: Mandjélia Mount or Tidiélic Mount, 780 m; 25 Oct. 2014); image $n^{\circ}$ P7314192. K-L. D. crassifolium Schltr., cult. Nouméa; 27 Nov. 2015. K. Image $n^{\circ} \mathrm{PB} 270172$. L. Image ${ }^{\circ} \mathrm{PB} 2700199$. M-N. D. camaridiorum Rchb.f., Bopope, Piémont (versant sud) du Kantalupaik, M. Pignal et al. 5165. N. Cult. Nouméa; 13 Nov. 2014; image n ${ }^{\circ}$ PB130988. O-Q, S-T. Habits. O. D. crassifolium Schltr., cult. Nouméa; before 1998; digitized analogue image s.n. P. D. unicarinatum Kores, Koghis Mountains, Bouo Mount, 680 m; 31 Aug. 2003; image ${ }^{\circ}$ P8311086. Q. D. camaridiorum Rchb.f., Vallée de la Tchamba; 15 Sep. 2003; image nP9151456. S. D. butinii M.Pignal \& Munzinger sp. nov., Vallée de la Amoa Vaawe; 26 Feb. 2016; image $\mathrm{n}^{\circ} \mathrm{P} 2260576$. T. D. letocartiorum Munzinger \& M.Pignal sp. nov., Mandjélia Mount ou Tidiélic Mount, 780 m; 24 Oct. 2018; image ${ }^{\circ} 111258$. R. Leaf of D. camaridiorum Rchb.f., J. Munzinger et al. 6358. A-L, N-S, T images by Christian Laudereau; M image by Jérôme Munzinger; R image by Peter P. Lowry. 
green, shiny above. Blade $49 \times 3 \mathrm{~mm}$. Midrib slightly prominent. Two lateral veins visible, $<1 \mathrm{~mm}$ from the margin (see discussion of anatomy below). Secondaries prominent, convergent at the apex. Base slightly narrower. Apex rounded or emarginate and asymmetrical. Sheath striated in the upper half and ending by a beak opposite to the lamina and applied on the stem. Inflorescence very short, 1-flowered. Ovary non-resupinate. Floral buds white, flower white to bright yellow when open, fleshy. Tepals with a red terminal dot. Dorsal sepal triangular, $4.5 \mathrm{~mm}$ long, $3 \mathrm{~mm}$ wide at the base, with 5 nerves. Lateral sepals triangular-ovate, oblique, ca $4 \times 2.4 \mathrm{~mm}$, with 8 nerves. Petals ovate, asymmetrical, ca $4 \times 2 \mathrm{~mm}$, with 3 nerves. Lip white, entire, rectangular, ca $4 \times 2.8 \mathrm{~mm}$, with 5-7 nerves, 3 on the carina and 2-4 lateral. Apex triangular, rounded to obtuse. Carina ca $1 \mathrm{~mm}$ wide. Column $1.8 \mathrm{~mm}$ high and $1.5 \mathrm{~mm}$ wide. Fruit globose, ca $6 \times 9 \mathrm{~mm}$. Dried seed with transparent testa of $217 \times 48 \mu \mathrm{m}$, fusiform, with extremity and base slender. Right extremity slightly spiral. Hydrated seed ovate, sacciform. Cells cubic to polygonal, with extremities rounded, ca 48-100 $\times 5 \mu \mathrm{m}$, with edges thick, roughly spiral, with smooth cellular walls. Embryo spherical, ca $12 \mu \mathrm{m}$ in diameter.
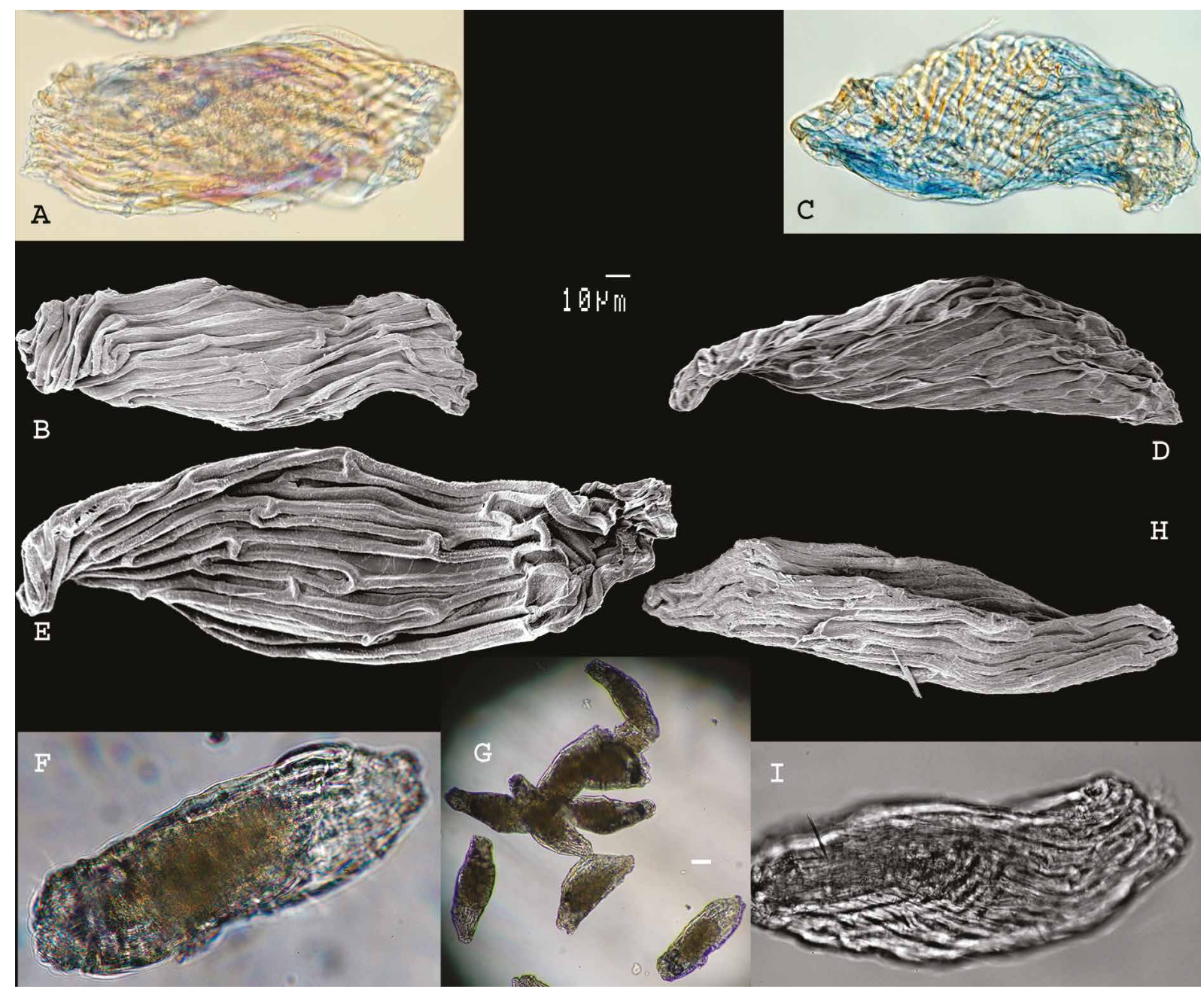

Fig. 3. Seeds, opening on the right. A-B. D. camaridiorum Rchb.f. A. LM. B. SEM (H.S. MacKee 14228). C-D. D. butinii M.Pignal \& Munzinger sp. nov. C. LM. D. SEM (M. Pignal 2384). E-G. D. letocartiorum Munzinger \& M.Pignal sp. nov. E. SEM. F. LM. G. SEM (H.S. MacKee 37760). H-I. D. unicarinatum Kores. H. SEM (H.S. MacKee 36986). I. LM (H.S. MacKee 44925). Scale bars: A-F, $\mathrm{H}-\mathrm{I}=10 \mu \mathrm{m} ; \mathrm{G}=30 \mu \mathrm{m}$. 


\section{Distribution and ecology}

Dendrobium unicarinatum grows in Fiji and in New Caledonia dense humid forest (500-750 m), as an epiphyte on trunks (at the base or at several metres high) and can be very abundant, especially on palms. C. Laudereau (pers. comm.) separates two populations by habit and light exposition: the first erect and in sunny situations, the other pendulous, in shade.

\section{Taxonomic notes}

In New Caledonia, D. unicarinatum can be easily identified by a cylindrical or slightly flattened stem, 1 -flowered inflorescence and white, non-resupinate flowers. Leaf section shows D. unicarinatum to be the only graminoid New Caledonian Dendrobium having large, obvious and numerous $(>20)$ supernumerary fibre bundles on both sides, and having the largest vascular bundle in position 2 .

\section{Phenology}

Further observations are needed to determine the flowering and fruiting periods. In the available herbarium material, flowers were observed on cultivated plants (grown in New Caledonia) in January and in the field from February to March, and fruits in May to January.

\section{IUCN status}

This species was not recognized in New Caledonia until now, and was evaluated as Data Deficient (DD) by the New Caledonian Red List Authority.

Dendrobium camaridiorum Rchb.f.

Figs 1E, M-N, Q-R, 3A-B, 4Bb, 5A-B, 6

Linnaea 41: 89 (Reichenbach 1877). - Type: NEW CALEDONIA • Balade; Vieillard 1332 (nec 1192); lectotype: $\mathrm{W}$, here designated; isolectotype: P[P00124865]!.

\section{Material examined}

NEW CALEDONIA - Deplanche 528bis; P[P00124867, P00124868] • Legand 4888; P[P00124869] - s. loc., cultivated in Parc E. Liais, Cherbourg-en-Cotentin; 5 Apr. 2003; M. Pignal 2046; (original data: collected alive in 1985 in New Caledonia); P[P00777178]. - Province Nord - Haute vallée de la Tchamba; [ $21^{\circ} 1^{\prime} 55^{\prime \prime} \mathrm{S}, 165^{\circ} 13^{\prime} 36^{\prime \prime} \mathrm{E}$; ; alt. 100-200 m; gallery forest, near the river; 28 Dec. 1965; H.S. MacKee 13753; P[P00124850] • Haute vallée de l'Amoa (exploitation forestière Létocart); [21 $\left.{ }^{\circ} 0^{\prime} 2^{\prime \prime} \mathrm{S}, 165^{\circ} 14^{\prime} 31^{\prime \prime} \mathrm{E}\right]$; alt. 300-500 m; humid forest; 13 Jan. 1966; H.S. MacKee 14228; P[P00124838, P00124849] • Haute Amoa; [2058'24" S, 165¹0'21" E]; alt. 50-100 m; humid forest; 20 Nov. 1967; H.S. MacKee 17984; $\mathrm{P}[\mathrm{P} 00124846, \mathrm{P} 00124874]$ - Haute Tchamba (exploitation forestière Letocart); [21 $\left.{ }^{\circ} 1^{\prime} 11^{\prime \prime} \mathrm{S}, 165^{\circ} 13^{\prime} 46^{\prime \prime} \mathrm{E}\right]$; alt. 500 m; humid forest; 21 Nov. 1967; H.S. MacKee 17991; P[P00124872]

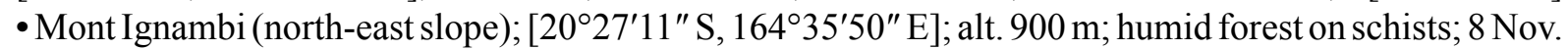
1971; H.S. MacKee 24639; P[P00124845] • Ponérihouen: east buttress of Mont Aoupinié; [21 ${ }^{\circ} 11^{\prime} 0^{\prime \prime}$ S, $\left.165^{\circ} 17^{\prime} 48^{\prime \prime} \mathrm{E}\right]$; alt. 700-850 m; humid forest on grauwackes; 28 Jun. 1972; H.S. MacKee 25626; P[P00124844] • Farino, Pic Vincent; [ $21^{\circ} 2^{\prime} 48^{\prime \prime}$ S, $165^{\circ} 10^{\prime} 8^{\prime \prime}$ E]; alt. 700 m; humid forest; 3 Mar. 1973; H.S. MacKee 26374; P[P00124843] • Haute Diahot, Tendé, exploitation forestière Frouin; [20²4'37" S, 16431'19" E]; alt. 600 m; humid forest, micaschists; 26 Apr. 1976; H.S. MacKee 31162; P[P00124839] - Roche Ouaième; [20³8'35" S, 16451'36" E]; alt. 850 m; maquis, schists; 22 Dec. 1977; H.S. MacKee 34465 (leg. Cherrier); P[P00121154] • Monéo; [21ㅇ'21" S, 165²7'51" E]; alt. 250 m; altered serpentine plateau, maquis; 25 Apr. 1979; H.S. MacKee 36818; P[P00124877] • Pouébo: Mont Mandjélia; [20²4'9" S, 164³1'28" E]; alt. 700 m; humid forest, micaschists; 8 Feb. 1981; H.S. MacKee 38729 (leg. Bégaud); P[P00124870] • Mandjélia, forested slopes; [20²4' S, 164³2' E]; alt. 500 m; 20 Dec. 1981; 
G. McPherson 4531; MO • Ponandou River Valley, forested slopes below Mont Inédète; $20^{\circ} 49^{\prime} 10^{\prime \prime} \mathrm{S}$, $165^{\circ} 11^{\prime} 18^{\prime \prime}$ E; alt. $550 \mathrm{~m}$; 10 May 2002; G. McPherson 18723; MO • Cascade la Guen; 19 Nov. 2010; J. Munzinger 6358, P. Lowry, M. Callmander, H. Vandrot, T. \& M. Teimpouene; MO • Bopope, base of the Kantalupaik (south buttress), summit of the Inédète range; $20^{\circ} 51^{\prime} 7^{\prime \prime} \mathrm{S}, 165^{\circ} 0^{\prime} 28^{\prime \prime} \mathrm{E}$; alt. $320 \mathrm{~m}$; 28 Dec. 2017; fl.; M. Pignal 5165, J. Munzinger \& D. Bruy; P[P01073021] • Balade; [20 18'56" S, 164²9'52" E]; s.d.; E. Vieillard 1332; P[P00124865] • Mont Görö Até; 211'42" S, $165^{\circ} 10^{\prime} 12^{\prime \prime}$ E; 19 Nov. 2002; F. Tronchet 484, J. Munzinger, D. Létocart, I. Létocart, J.-P. Butin, A. Oddi \& A. Obry;

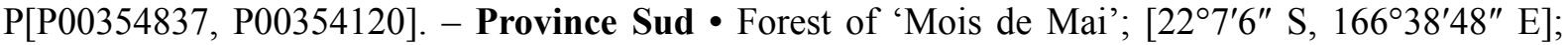
13 Jun. 1951; M.G. Baumann-Bodenheim 14050; P[P00124861] • ibid.; 24 Jun. 1951; M.G. BaumannBodenheim 14179; P[P00124860] • Mont “Algaoné" [Algaoué], serpentine; [22¹2'10" S, 166 31'40" E]; alt. 500 m; 19 Dec. 1950; A. Guillaumin 7031 \& M.G. Baumann-Bodenheim; P[P00124859] • Mé Amméri; [2139'34" S, 16550'36" E]; alt., 700 m; 27 Nov. 1950; A. Guillaumin 8647 \& M. G. BaumannBodenheim; P[P00124852] • ibid.; 27 Nov. 1950; A. Guillaumin 8700 \& M.G. Baumann-Bodenheim; $\mathrm{P}[\mathrm{P} 00124851] \bullet$ ibid.; 28 Nov. 1950; A. Guillaumin 8744 \& M.G. Baumann-Bodenheim; $\mathrm{P}[\mathrm{P} 00124854]$ - ibid.; 28 Nov. 1950; A. Guillaumin 8721; P[P00124748] • ibid.; 28 Nov. 1950; A. Guillaumin 8780 \& M.G. Baumann-Bodenheim; P[P00124853] • ibid.; 28 Nov. 1950; A. Guillaumin 8882 \& M.G. BaumannBodenheim; P[P00124855] • ibid.; 29 Nov. 1950; A. Guillaumin 8938 \& M.G. Baumann-Bodenheim; $\mathrm{P}[\mathrm{P} 00124856] \bullet$ ibid.; 29 Nov. 1950; A. Guillaumin 8969 \& M.G. Baumann-Bodenheim; $\mathrm{P}[\mathrm{P} 00124858]$ - ibid.; 30 Nov.1950; A. Guillaumin 9030 \& M.G. Baumann-Bodenheim; P[P00124864] • Forest of Rivière Bleue; [22 $\left.6^{\prime} 11^{\prime \prime} \mathrm{S}, 166^{\circ} 38^{\prime} 0^{\prime \prime} \mathrm{E}\right] ; 22$ Feb. 1951; A. Guillaumin 10965 \& M.G. BaumannBodenheim; P[P00124857] • ibid.; A. Guillaumin 10966a \& M.G. Baumann-Bodenheim; P[P00124863] - Mont Bario; [22¹0'54" S, 166³0'18" E]; alt. 500 m; 20 Apr. 1951; A. Guillaumin \& M.G. BaumannBodenheim 12523a; $\mathrm{P}[\mathrm{P} 00124862]$ - Farino: forest of Mépéou (Exploitation forestière Germain); [2137'5" S, 16546'35" E]; alt. 500 m; humid forest; 11 Feb. 1966; H.S. MacKee 14412; P[P00124848, P00124873] • Col d'Amieu: Mont Pembai; [2134'36" S, 16549'38" E]; alt. 500-600 m; humid forest; 10 Jun. 1973; H.S. MacKee 26765; P[P00124842] • ibid.; H.S. MacKee 26766; P[P00124841] • Port

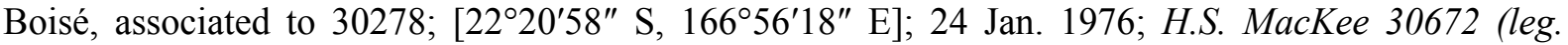
Aymard); P[P00124840] • 4 km west of Mé Aoui; [21 $\left.25^{\prime} 27^{\prime \prime} \mathrm{S}, 165^{\circ} 32^{\prime} 6^{\prime \prime} \mathrm{E}\right]$; alt. $600 \mathrm{~m}$; humid forest, schists; 31 Oct. 1976; H.S. MacKee 32173 (leg. Bégaud); P[P00124847] • Port Boisé; [22²0'59" S,
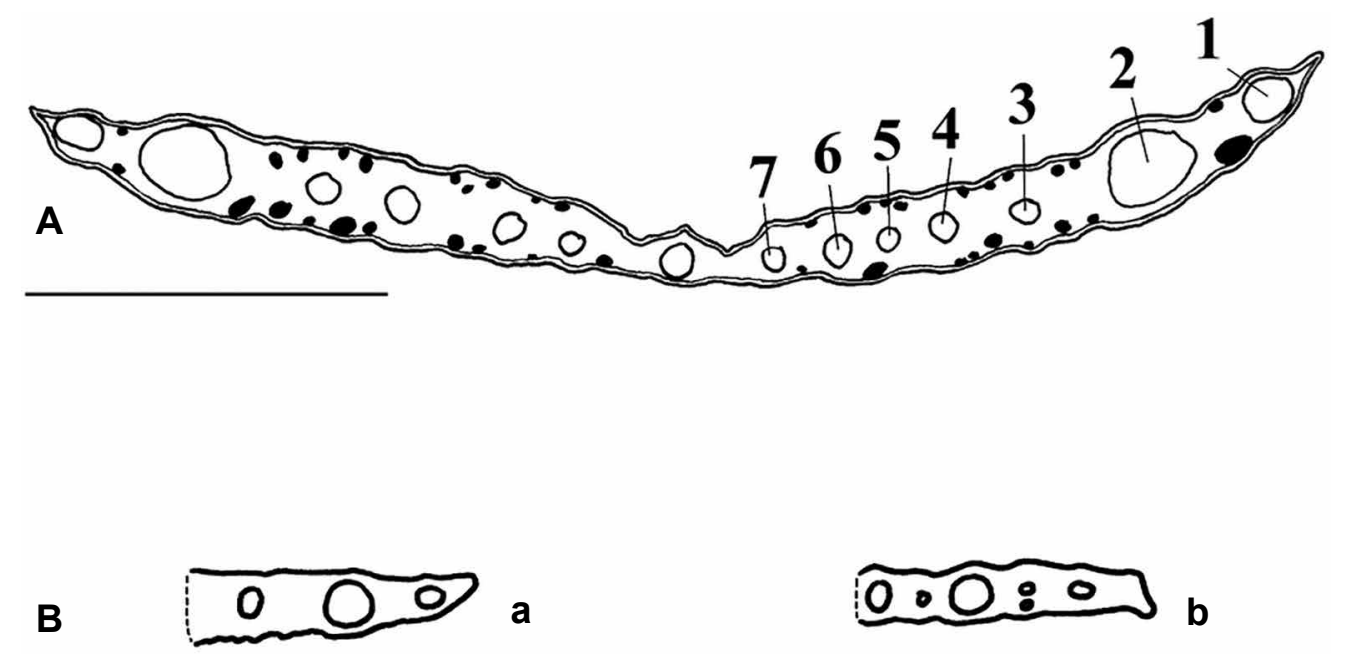

Fig. 4. Drawing of transverse sections of leaves of three graminoid species of Dendrobium. A. Total section of D. unicarinatum Kores (H.S. MacKee 44925). Vascular bundles are represented by empty circles and are numbered starting from the lamina margin, black spots indicate fibre bundles. B. Leaf margins sections, a. D. letocartiorum Munzinger \& M.Pignal sp. nov. (H.S. MacKee 37760); b. D. camaridiorum Rchb.f. (H.S. MacKee 24639). Scale bar $=1 \mathrm{~mm}$. 


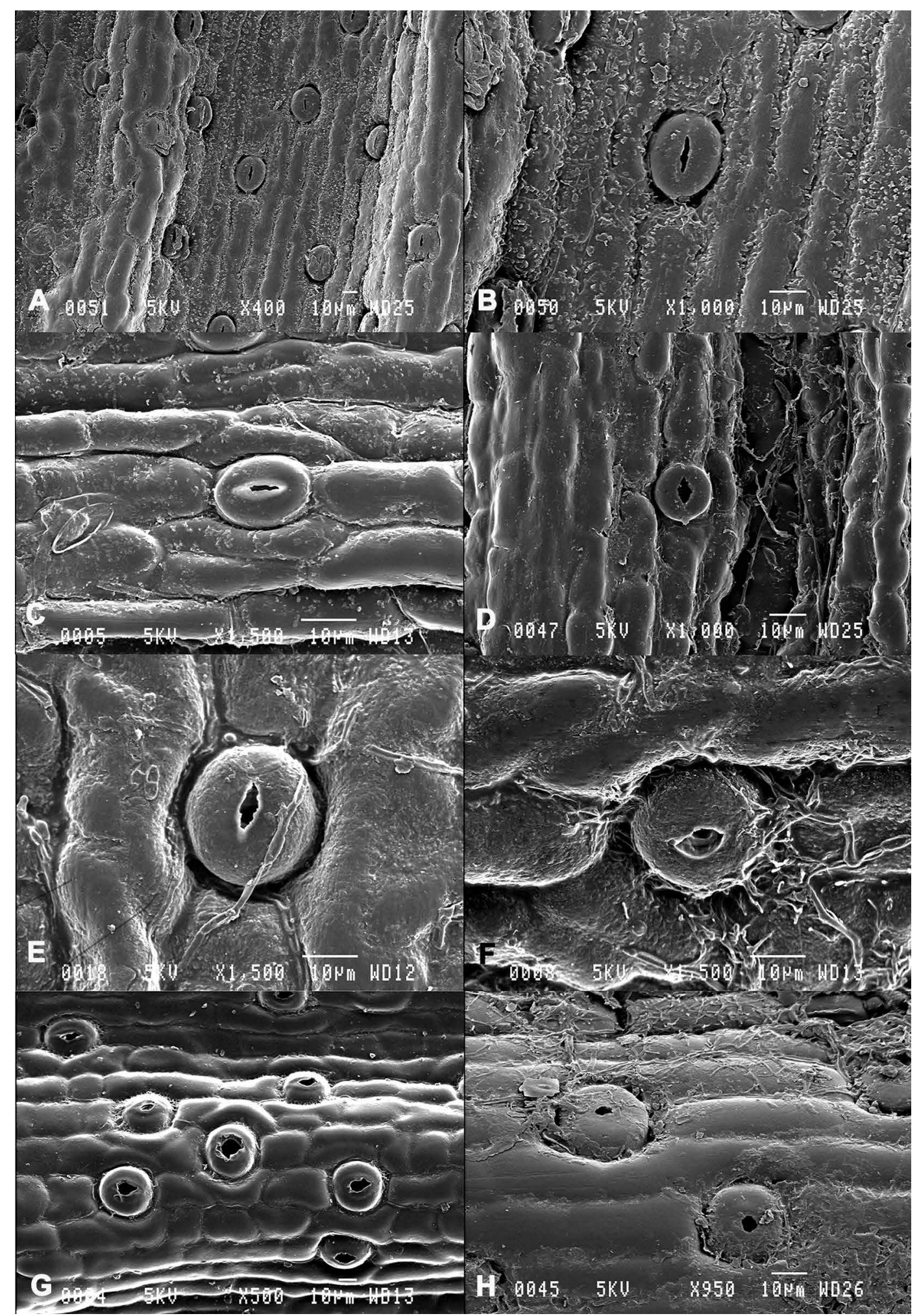

Fig. 5. Stomata (SEM). A-B. Type I: D. camaridiorum Rchb.f. (H.S. MacKee 14228). C. Type I: D. butinii M.Pignal \& Munzinger sp. nov. (M. Pignal 2384). D. Type II: D. butinii M.Pignal \& Munzinger sp. nov. (M. Pignal 2384). E. Type I: D. crassifolium Schltr. (H.S. MacKee 43781). F. Type II: D. crassifolium Schltr. (H.S. MacKee 43781). G. Type II: D. letocartiorum Munzinger \& M.Pignal sp. nov. (H.S. MacKee 37760). H. Type II: D. unicarinatum Kores (H.S. MacKee 36986). Scale bars $=10 \mu \mathrm{m}$. 
16656'19" E]; 9 May 1978; H.S. MacKee 35091 (leg. Bégaud); P[P00124878] • Paita: Tao; [20³4'24" S, 16447'57" E]; 8 Apr. 1982; H.S. MacKee 40310 (leg. Bégaud); P[P00121153] • Piste du Dzumac; [224'46" S, 166²6'34" E]; alt. 800 m; 16 Mar. 1985; H.S. MacKee 42497 (leg. Aymard); P[P00124875]

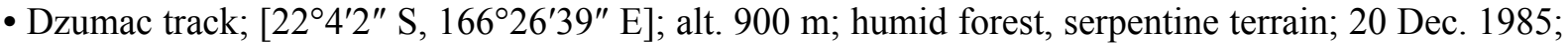
H.S. MacKee 42955 (leg. Aymard); P[P00124871] - Thy River valley, ca 12 air-km NE of Nouméa, rainforest near $400 \mathrm{~m}$; [20¹0'55" S, 166³1'19" E]; 8 Apr. 1979; G. McPherson 1530; P[P00124876];

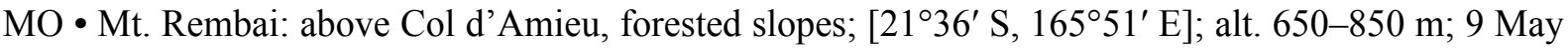
1984; G. McPherson 6542; P[P00124876]; MO • Flanc du Mont Dore; [22¹7'36" S, 166³5'17" E]; s.d.; Musée Néocalédonien 394; P[P00124866].

\section{Description}

Epiphyte (also lithophytic), erect with graminoid habit. Roots whitish, ca 1-2 mm wide, at the base of the plant (axillary roots lacking, but sometimes with adventive rooted plantlets, 'keikis'). Stems spindly, $20-70 \mathrm{~cm}$ long, cylindrical, covered by the sheaths of the oldest leaves, lamina remaining only from the upper middle to the upper third of the adult stem. Lamina narrow and long, 45-100 $\times 4-5 \mathrm{~mm}$, apex attenuated, carrying a V-shaped depression under half of its length (Fig. 1R). Internodes $25-30 \mathrm{~mm}$ long at the base of the stem. Sheaths deeply furrowed, beak opposite to the lamina, flute-shaped. Inflorescences always 2 -flowered. Ovary resupinate. Flower white, fragrant. Sepals long, narrow, attenuated, ca $35 \times 2 \mathrm{~mm}$. Petals long and narrow, equaling the sepals, $30 \times 2 \mathrm{~mm}$. Lip trilobate, lateral lobes rounded, median lobe ending as a point, the lip with orange deep within. Central carina proximal, without papillose hairs, edge slightly toothed. Dots yellow-orange on the mentum and the carina. Mentum $4 \mathrm{~mm}$ long. Column $3 \mathrm{~mm}$ long. Fruit fusiform, greenish yellow, ca $15 \mathrm{~mm}$ long and $8 \mathrm{~mm}$ in diameter. Dried seed with transparent testa about $191 \times 54 \mu \mathrm{m}$, fusiform, with extremity and base truncate. Extremity strongly spiral. Hydrated seed ovate

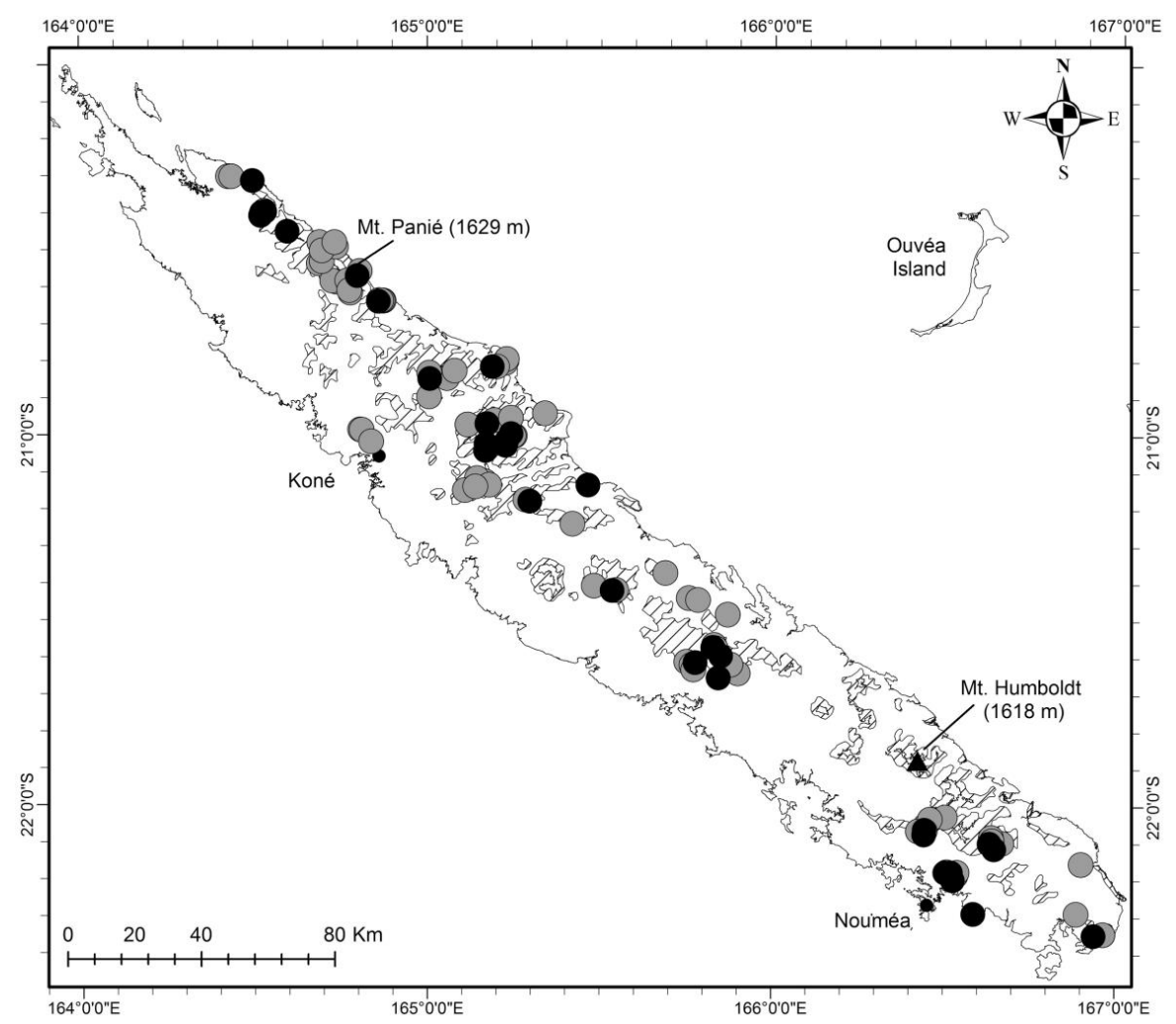

Fig. 6. Distribution of D. camaridiorum Rchb.f., based on herbarium specimens $(\mathbf{O})$ and field observations (O). 
sacciform. Cells cubic or with extremities rounded, elongate, ca 57-100 $\times 7.3-8.5 \mu \mathrm{m}$, edges thick with spiral orientation, cellular walls smooth. Embryo spherical ca 10-11 $\mu \mathrm{m}$ in diameter (Fig. 3A-B).

\section{Distribution and ecology}

The endemic plant is widespread in humid or gallery forests all over the main island 'Grande-Terre', from 50 to $900 \mathrm{~m}$, but has not been observed in sclerophyll forest (west coast), or in the extreme northwest (Fig. 6).

\section{Taxonomic notes}

Dendrobium camaridiorum produces numerous adventive plantlets ('keikis'), which is not the case of $D$. butinii sp. nov. The long, attenuated leaves with a V-shaped depression on the blade surface are the easiest characters to observe in D. camaridiorum. It is distinguished from $D$. butinii sp. nov. by the white, very elongated sepals (shorter and green in $D$. butinii sp. nov.). Leaf anatomy shows $D$. camaridiorum very similar to $D$. letocartiorum sp. nov. (see details under $D$. letocartiorum sp. nov. below).

\section{Phenology}

Flowers are observed throughout the year. It seems that the hours of opening (in the morning) and closing of the flowers (in the afternoon) are synchronous throughout the territory.

\section{IUCN status}

Dendrobium camaridiorum is the most abundant species of the graminoid group in New Caledonia, and was evaluated as Least Concern (LC) by the New Caledonian Red List Authority.

\section{Typification}

Vieillard's numeration cannot be understood as true collection numbers (Morat 2010). Indeed, he often attributed the same number to different gatherings that he regarded as comprising a single species, however he confused many taxa, thereby generating some nomenclatural problems as many of his collections were chosen as types (see for example Pierre et al. 2014). Comparison of the material deposited at W with a specimen at $\mathrm{P}$ that clearly represents the same collection indicates that an error occurred in transcribing the number on the former, which is probably a fragment removed from the original specimen. Labels on the Paris specimen bear the number Vieillard 1332, whereas the sheet at W is numbered 1192, which in fact corresponds to material of Phyllanthus cornutus Baill. (Euphorbiaceae Juss.). The material in Vienna consists of a stem fragment, several leaves, a single, dissected, immature flower, and a drawing of the Paris material. The latter is a tracing of the Paris plant (Hallé, pers. comm.). This interpretation is consistent with Reichenbach's visit to P in April 1864 (Paris Herbarium Visit Catalogue). Paris's material comprises a bud and a tuft of 3 stems, and is clearly conspecific with the fragmentary collection at W. We can reasonably assume that Reichenbach studied both $\mathrm{P}$ and $\mathrm{W}$ material, which would thus represent syntypes. We have selected the material at $\mathrm{W}$ as the lectotype as it clearly served as the basis of the description of the flower.

\section{Dendrobium crassifolium Schltr.}

Figs $1 \mathrm{~K}-\mathrm{L}, \mathrm{O}, 5 \mathrm{E}-\mathrm{F}, 7$

Botanische Jahrbücher für Systematik, Pflanzengeschichte und Pflanzengeographie Heft 1, 39: 75 (Schlechter 1906). - Type: NEW CALEDONIA - Province Nord • près "Ou-Hinna" [Oua Hinna]; alt. 900 m; 2 Jan.1903; Schlechter 15603; holotype: B (destroyed); lectotype: P[P00121168]!, here designated; isolectotype: $\mathrm{K}$ [K001085479] photo seen, $\mathrm{BM}$ [BM000505888] photo seen). 


\section{Etymology}

The epithet refers to the texture of the leaf.

\section{Material examined}

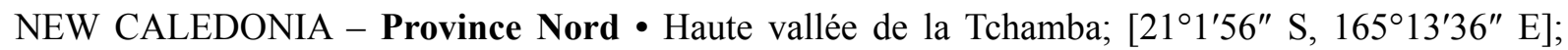
alt. 100-200 m; gallery forest near the river; 28 Dec. 1965; fl.; H.S. MacKee 13751; P[P00124990]

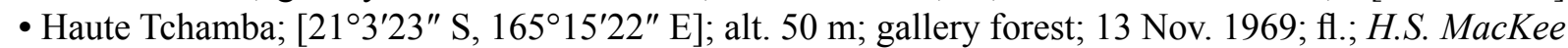
21172; P[P00124992], P[P00124993], P[P00124994] • Plateau of the Dôme Tiébaghi; [20²7'37" S, 164¹2'7" E]; alt. 500 m; 20 Jun. 1972; fl.; H.S. MacKee 21337; P[P00124991] • Touho, Ponandou;

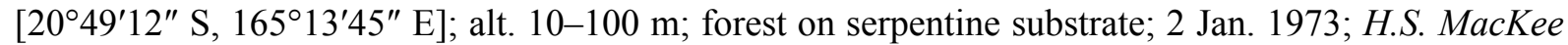

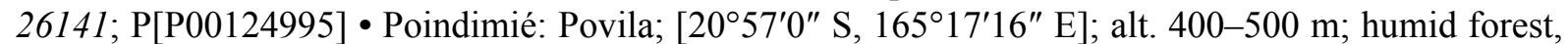
schistose crest; 21 Mar. 1975; H.S. MacKee 29892; P[P00124996] • Touho: Ponandou; [2049'11" S, 165'14'14" E]; alt. 30 m; gallery forest, schists; 22 Mar. 1975; H.S. MacKee 29897; P[P00124997]

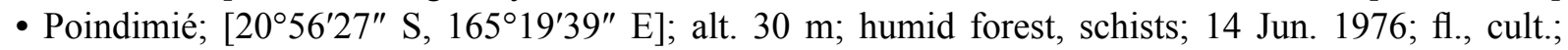
H.S. MacKee 31399 (leg. Aymard); P[P00124998] • Haute Amoa: base du Mont Grandié; [2058'59" S, $\left.165^{\circ} 9^{\prime} 15^{\prime \prime} \mathrm{E}\right]$ alt. $50 \mathrm{~m}$; gallery forest, serpentine substrate; 25 Dec. 1976; fl.; H.S. MacKee 32136;

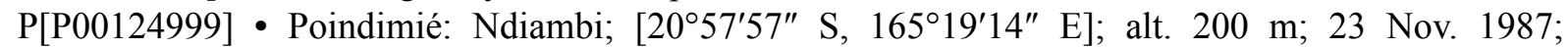
H.S. MacKee 43781 (leg. Aymard); P[P00123284], P[P00354112 alc.] • Flowered in greenhouse in Nov. 1983; P. Morat 5321 (original data: Bopope, Feb. 1977, collected by P. Morat); P[P00121169] • On the

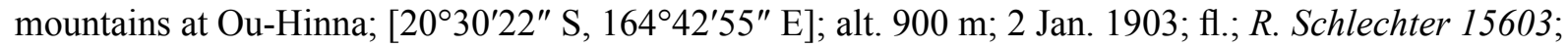
P[P00121168]. - Province Sud • Haute Yaté, Rivière Bleue; [22 ${ }^{\circ} 6^{\prime} 46^{\prime \prime} \mathrm{S}, 166^{\circ} 41^{\prime} 4^{\prime \prime}$ E]; alt. 200 m; humid forest, serpentine substrate; 1 Feb. 1985; H.S. MacKee 42443 (leg. Bégaud); P[P00125000] - On the

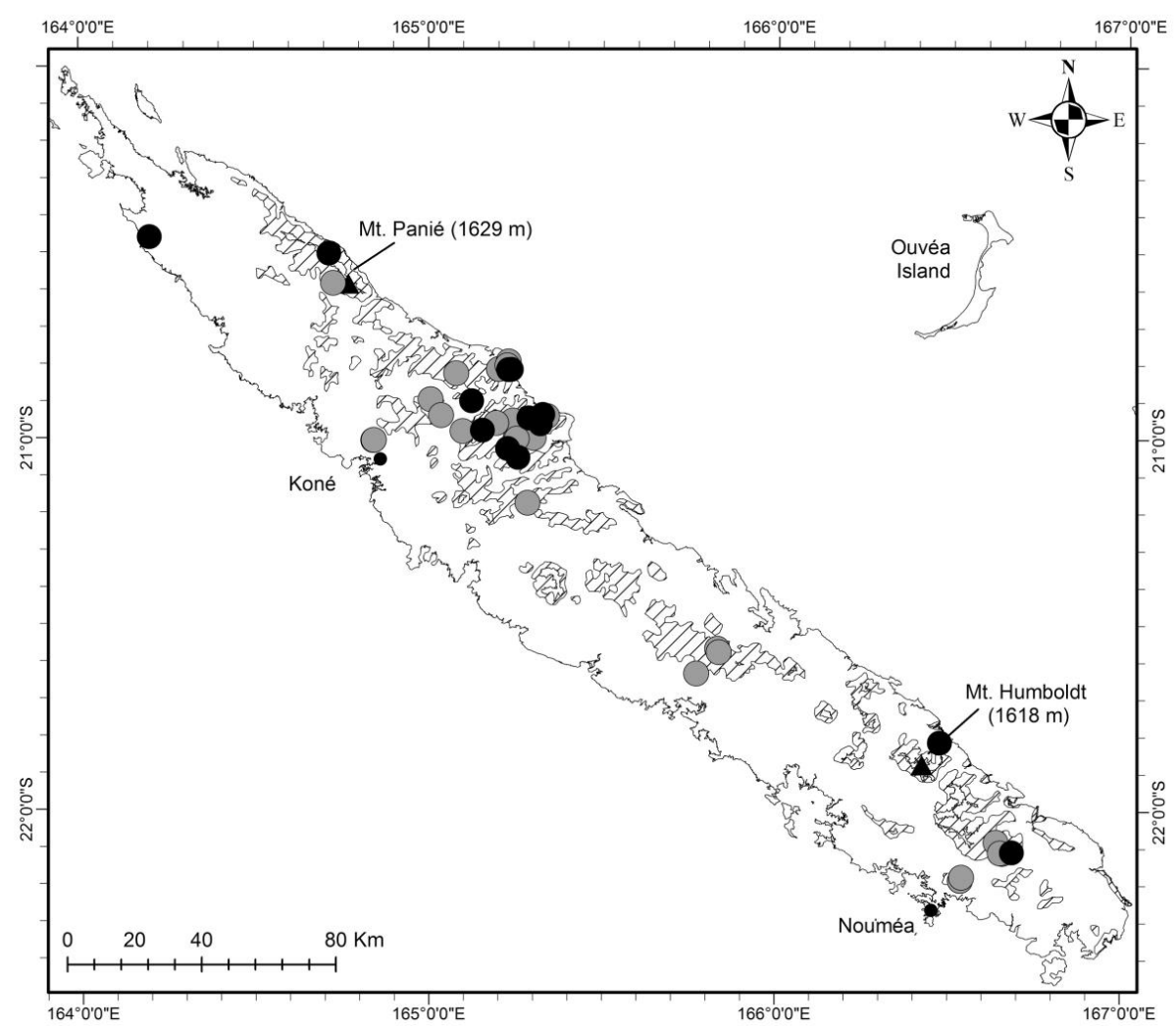

Fig. 7. Distribution of D. crassifolium Schltr., based on herbarium specimens $(\mathbf{O})$ and field observations (O). 


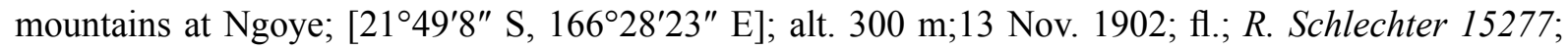
LY[LY0562048].

\section{Description}

Erect or downward arching epiphyte. Roots whitish, ca 1-2 mm wide, at the base of the plant (axillary roots lacking). Stems 20-100 cm long, robust. Sheaths of the oldest leaves not always covering the stem. Leaves dark green shiny above, lighter below, thick and coriaceous. Lamina shortly ovate to elliptic, $50-70 \times 9-15 \mathrm{~mm}$. Midrib visible, secondaries weakly visible. Lamina with a visible V-shaped depression printed around the lower third of the stem. Base abruptly narrowed, apex attenuate, emarginate, with two sub-equal lobes. Sheath striated in its entire length, with edge oblique, opposite to the lamina and applied to the stem. Inflorescence 2-flowered. Ovary resupinate. Flower yellow. Sepals triangular, $10 \times 2.9 \mathrm{~mm}$. Petals elliptical, $10 \times 2.5 \mathrm{~mm}$. Lip trilobed ca $6 \times 5 \mathrm{~mm}$. Lateral lobes with papillose hairs, median lobe with distinctive carina, extending into short papillate hairs. Edge slightly fimbriate. Mentum ca $3 \mathrm{~mm}$. Column about $1.7 \mathrm{~mm}$ long. Fruit fusiform ca $8 \times 10 \mathrm{~mm}$ long and $8 \mathrm{~mm}$ in diameter. Seed not seen.

\section{Distribution and ecology}

This endemic species is found in a broad ecological range, quite commonly scattered in several places on the main island 'Grande-Terre' (Fig. 7), an epiphyte in humid or gallery forest. It grows from near sea level $(10 \mathrm{~m})$ to $900 \mathrm{~m}$.

\section{Taxonomic notes}

In New Caledonia, in the sect. Grastidium, D. crassifolium is the only species to have parts of the perianth rounded at the apex. Dendrobium crassifolium has the thickest leaves of the graminoid New Caledonian Dendrobium, it is also the only species having vascular bundles in two lines (vs one), more than 32 vascular bundles (vs $<30$ ), and the largest vascular bundle with diameter $<1 / 2$ the thickness of the leaf blade (vs $>3 / 4$ the thickness).

\section{Phenology}

Flowering probably throughout the year (not observed in April).

\section{IUCN status}

The species is common in New Caledonia and was evaluated as Least Concern (LC) by the New Caledonian Red List Authority.

Dendrobium butinii M.Pignal \& Munzinger, sp. nov.

urn:lsid:ipni.org:names:77209475-1

Figs 1A, H, S, 3C-D, 5C-D, 8, 9

\section{Diagnosis}

Dendrobium camaridiorum Rchb.f. affinis, sed planta gracilior foliis minoris fastigiatisque cum vagina minus sulcata, radicibus axillaribus, sepalis brevioris acuminatisque, petalis brevioris angustiorisque. Lobus medius labeli frimbriatus papillosusque.

\section{Etymology}

The species is dedicated to our good friend, Jean-Pierre Butin, an enthusiastic lover of botany, who first recognized and collected this taxon. 

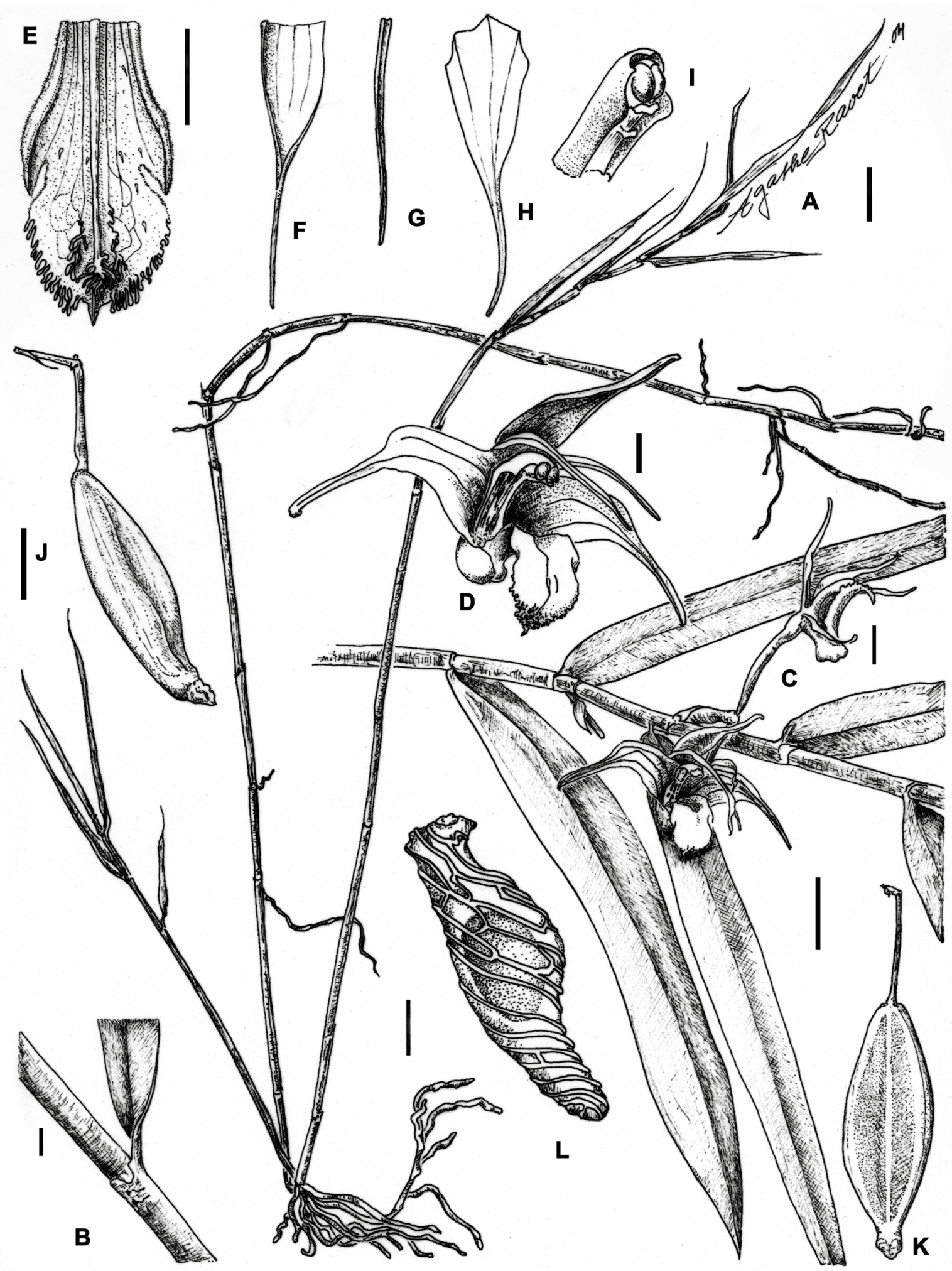

Fig. 8. Dendrobium butinii M.Pignal \& Munzinger, sp.nov. Butin s.n. A. Habit. B. Sheath. C. Inflorescence. D. Flower. E. Lip. F. Dorsal sepal. G. Petal. H. Lateral sepal. I. Column. J. Fruit, profile. K. Fruit, face. L. Seed. Scale bars: A, C $=1 \mathrm{~cm}, \mathrm{~B}, \mathrm{E}-\mathrm{I}=2 \mathrm{~mm}, \mathrm{D}=1 \mathrm{~mm}, \mathrm{~J}-\mathrm{K}=5 \mathrm{~mm}, \mathrm{~L}=3.5 \mu \mathrm{m}$ (A-B, E-L, J.-P. Butin s.n. [P00157228], C-D from a picture of J.-P. Butin). Drawing by Agathe Haevermans. 


\section{Type material}

NEW CALEDONIA - Province Nord - s. loc.; 18 May 2001; fl.; J.-P. Butin s.n.; (original data: Mont Colnett 700 m, collected alive by J.P. Butin, 3 Oct. 1997); holotype: P[P00157228]!; clonotype: $\mathrm{P}[\mathrm{P} 00453885]$ ! (see note).

\section{Paratypes}

NEW CALEDONIA - Province Nord • Cultivated in Koné; 7 May 2003; fl.; J.-P. Butin s.n.; (original data: Mont Colnett, collected by J.P. Butin); P[P00453886] - Mont Colnett; 20²9'17" S, 16442'42" E; alt. 690 m; 10 May 2003; fl. \& fr.; J.-P. Butin s.n.; P[P00777172, P00777173] • Amoa GR Tchamba, Poindimié; 2059'2" S, 165¹3'55" E; 13 Nov. 2016; fl. \& fr.; C. Laudereau 133; NOU[NOU090367]

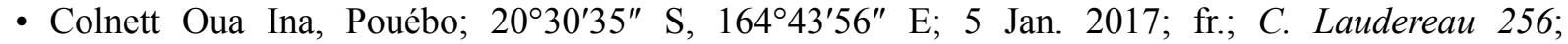
NOU[NOU090368] • Colnett Oua Ina, Pouébo; 20³0'38" S, 16444'0" E; 2 Jan. 2018; C. Laudereau 663; NOU[NOU090369] - Poindimié, Povila, Nérupaawé Pic Amoa; 2057'25" S, 165¹7'27" E; 21 Oct. 2018; fl.; C. Laudereau 1061 \& D. Szlachetko; NOU[NOU090370] • Ouane Batch, Pouébo; $20^{\circ} 30^{\prime} 35^{\prime \prime}$ S, 16443'56" E; 23 Oct. 2018; fr.; C. Laudereau 1115 \& D. Szlachetko; NOU[NOU090371]

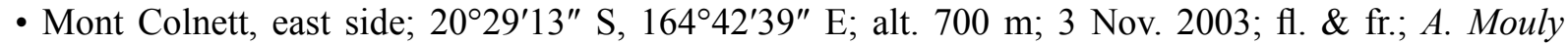

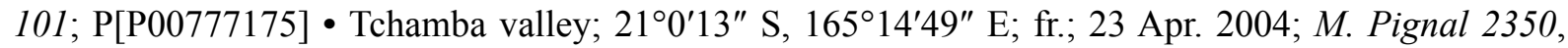
J. Munzinger, J.P. Butin, C. Létocart, I. Létocart \& D. Létocart; P[P02288380] - Tchamba valley; $21^{\circ} 0^{\prime} 34^{\prime \prime}$ S, 165'14'24" E; fr.; 24 Apr. 2004; M. Pignal 2384, J. Munzinger, J.-P. Butin, C. Létocart, I. Létocart \& D. Létocart; $\mathrm{P}[\mathrm{P} 00777174]$.

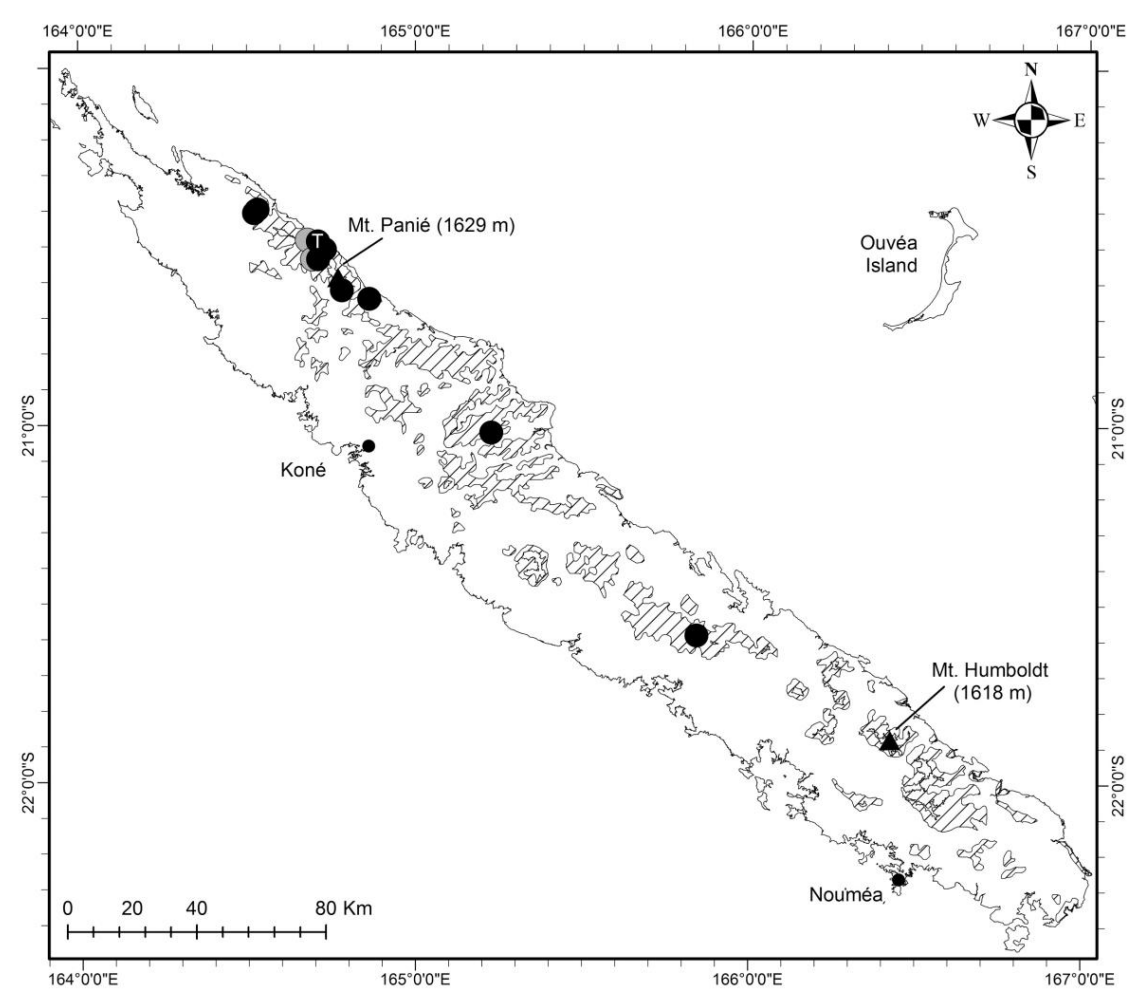

Fig. 9. Distribution of D. butinii M.Pignal \& Munzinger, sp. nov., based on herbarium specimens and field observations $(O)$, ' $T$ ' indicates the type collection. 


\section{Description}

Terrestrial or epiphytic herb with graminoid habit. Thin roots at the base of the plant, as well as along the stem, at the base of the nodes. Stems spindly $400 \times 1.5-2 \mathrm{~mm}$. Internodes $1-1.5 \mathrm{~cm}$ long. Sheaths of the dried leaves covering all of the stem, not deeply furrowed, the part opposite to the stem showing a beak-like extension. Leaves with narrow lamina, ca $2 \mathrm{~mm}$ wide at the base and 35-40 $\mathrm{mm}$ long. Lamina with a visible V-shaped depression printed around the lower third of the stem. Inflorescence 2-flowered, emerging from a small sessile sheath. Ovary resupinate. Flowers: sepals triangular, greenish, $9 \times 3 \mathrm{~mm}$, abruptly acuminate, acumen of the sepal $4 \mathrm{~mm}$ long. Petals linear, very narrow, greenish, ca $7 \times 0.5 \mathrm{~mm}$. Lip yellow-green, trilobate, with small short papillate hairs on edges. Lateral lobes $1 \mathrm{~mm}$ wide, weakly carinate, each carina surmounted by the same small papillate hairs. Median lobe cordiform, $3 \mathrm{~mm}$ wide, ending in a central clearly distinguishable carina, laterally fimbriate, each fibre covered with small papillate hairs, ending by a tuft of thick long hairs. Internal face of the column with longitudinal reddish macules, $3 \mathrm{~mm}$ height, mentum showing a right angle with the ovary, $3 \mathrm{~mm}$. Ovary ca $2 \mathrm{~mm}$ long, on a peduncle $12 \mathrm{~mm}$ long. Fruit ellipsoid, ca $18 \times 4 \mathrm{~mm}$. Dried seed with transparent testa, $208 \times$ $53 \mu \mathrm{m}$, fusiform with extremity and base attenuated. Extremity strongly spiralled. Hydrated seed elliptic sacciform. Cells cubic to polygonal, ca $65 \times 4.6-6.6 \mu \mathrm{m}$, with spiral orientation. Edges thick, with spiral orientation, cellular walls smooth. Embryo spherical or elongate, about $8 \mu \mathrm{m}$ in diameter.

\section{Distribution and ecology}

This endemic species has been located so far on one mountain (Mont Colnett) and in one valley (Tchamba) and appears restricted to humid forest of the North-East of the main island. Dendrobium butinii sp. nov. appears to occur in areas with the same ecological conditions as those of D. unicarinatum.

It can also occur in windy areas, as a lithophytic cushion plant on mossy micashists, in a dense population of cushion-like plants (Butin, pers. comm.). The species is known from 280 to $700 \mathrm{~m}$ elevation. The species has been observed also in the forest of Sailles (Thio) and Pénari (C. Laudereau, pers. comm.).

\section{Taxonomic notes}

The material studied that we attribute to $D$. butinii sp. nov. clearly does not correspond to $D$. minutiflorum Kraenzl. (Kränzlin 1914: 84), which was considered an insufficiently known species by Hallé (1977) and was based on a single collection (Sarasin 579) that was probably destroyed in Berlin. According to the original description (Kränzlin 1914), D. minutiflorum has bilobed leaves that are $23 \mathrm{~mm}$ long and 6-7 mm wide, 2-3-flowered inflorescences, suggesting that this taxon would be closest to $D$. isochiloides Kraenzl. (Kränzlin 1894: 334) (=Monanthos isochiloides (Kraenzl.) Rauschert in Rauschert 1983: 455) and D. erectifolium J.J.Sm. (Smith 1908: 16) (=Monanthos erectifolius (J.J.Sm.) Rauschert in Rauschert 1983: 455). Hallé suggested this species might be related to members of sect. Grastidium, although the 3-flowered inflorescence would be very surprising inside this section. The ecological conditions in which the two taxa (D. minutiflorum and D. butinii sp. nov.) occur are also different: $D$. minutiflorum was collected at Yaté in extreme SE New Caledonia, at low altitude $(100 \mathrm{~m})$ in an area with ultramafic soil, whereas D. butinii sp. nov. grows between 450 and $700 \mathrm{~m}$ at sites with sedimentary substrates.

Dendrobium butinii sp. nov. matches the characters of the "fourth group" so called by Hallé (1977), characterized by having leaves along the stem, internodes hidden by leaf sheaths that are not imbricate and 2-flowered inflorescences on the leafy stems, opposite the lamina and developing from a small, sessile sheath. In New Caledonia this morphological group is represented by three species: D. butinii sp. nov., $D$. crassifolium and $D$. camaridiorum. This group is also remarkable by the presence of a 'V-like' central imprint on the leaves, always clearly present in D. camaridiorum and D. crassifolium, sometimes less apparent in D. butinii sp. nov. (Figs 1R, 8). 
Dendrobium camaridiorum is the closest species to D. butinii sp. nov. Based on habit, D. butinii sp. nov. can be distinguished by its more spindly aspect, its smaller leaves, the presence of numerous adventive roots without adventive plantlets ('keikis') and its abruptly narrowed sepals.

Floral features, including the presence of papillose hairs on the lip and its fimbriate aspect, suggest a close affinity between $D$. butinii sp. nov. and D. crassifolium, although the hairs and fibres are much more developed in the latter species. Dendrobium butinii sp. nov. has thin leaves and vascular bundles in one line as $D$. camaridiorum, but differ by having vascular bundles $<15$ (vs $>22$ ), midrib not prominent (vs prominent), largest bundles in position 3(4-5) (vs 5(-6)) and presence of supernumerary fibre bundles (vs absence). Dendrobium butinii sp. nov., D. camaridiorum and $D$. crassifolium were all observed by the authors growing together on a single tree trunk in the Tchamba valley in NE New Caledonia.

\section{Phenology}

Flowering and fructification periods need further observations. The fruits were observed from the field and in cultivation (in New Caledonia) in January, April to May, October to November. Flowering specimens were observed in January, April, May and October to November.

\section{IUCN status}

Even if uncommon, D. butinii sp. nov. was evaluated as Least Concern (LC) by the New Caledonian Red List Authority, because no specific threat to the species or its habitat is known.

\section{Note}

Unrecognised by the International Code of Nomenclature for algae, fungi, and plants (Turland et al. 2018), the clonotype notion is used by numerous systematicians working on groups which can be cultivated. By 'clonotype' we designate here all material originated from the individual which provided the holotype and isotypes. Thus, the collector of a clonotype and the collection date can be different from those of the 'type' material. According to the Code, this is a paratype, but it can be genetically equated to an isotype; thus we believe the clonotype notion should be accepted by the Code.

Dendrobium letocartiorum Munzinger \& M.Pignal, sp. nov. urn:lsid:ipni.org:names:77209476-1

Figs $1 \mathrm{C}-\mathrm{D}, \mathrm{F}-\mathrm{G}, \mathrm{T}, 3 \mathrm{E}-\mathrm{G}, 4 \mathrm{Ba}, 5 \mathrm{G}, 10,11$

\section{Diagnosis}

Dendrobium bilobo Lindl. affinis, sed foliorum rostratis vaginis (versus truncatas), sine atropurpureis maculis labello, dorsali sepalo triangulari, $12 \times 2 \mathrm{~mm}$ (versus ovatum 4-5 $\times 2-3 \mathrm{~mm}$ ), lateralibus sepalis $12 \times 4 \mathrm{~mm}$ (versus $6.5 \times 4.5 \mathrm{~mm}$ ), petalis linearis vel paulo lanceolata, $11 \times \mathrm{ca} 1 \mathrm{~mm}$ (vs lanceolata, $3.5-4 \times 1.5-2 \mathrm{~mm}$ ), gynostegio cum atropurpureis faciali interni maculis (vs pallide purpureis aut albis), praecipue differt.

\section{Etymology}

The species is dedicated to our friends Irène and Daniel Létocart who collected and cultivated this plant in 1978-1980, providing H.S. MacKee with material for the first herbarium specimens, and also to the Létocart family, whose many members are active naturalists, creators of the Endemia website, and with whom we have made many field trips. 

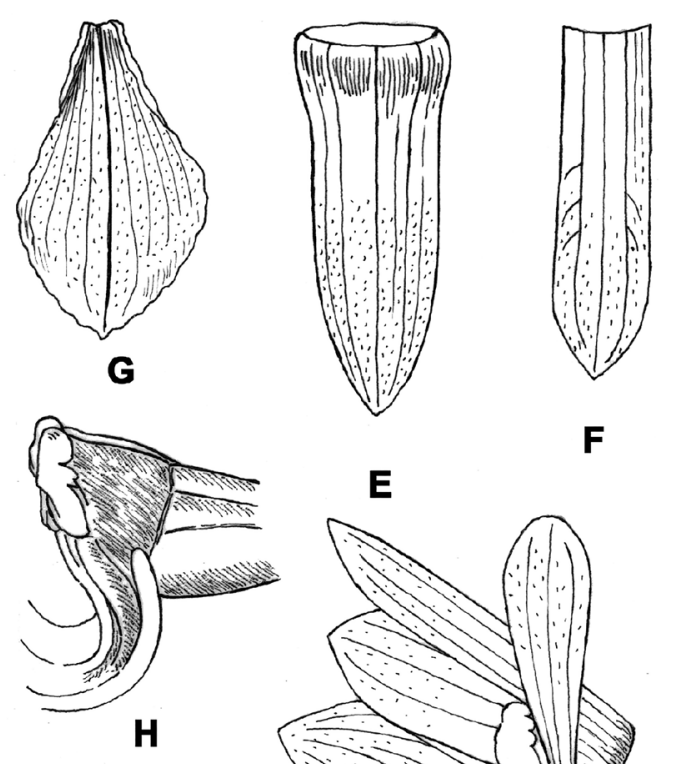

$\mathbf{F}$

E
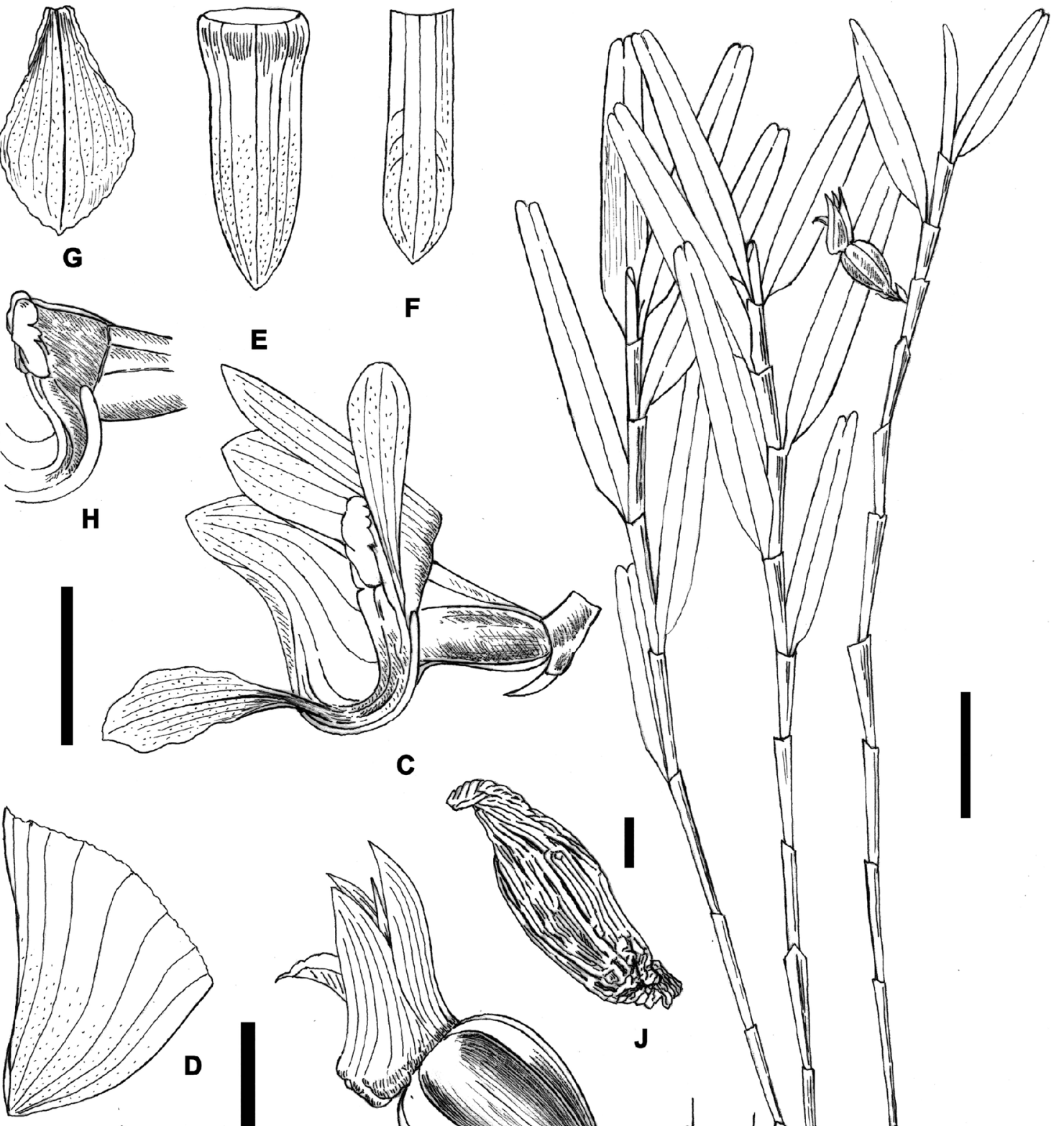

C
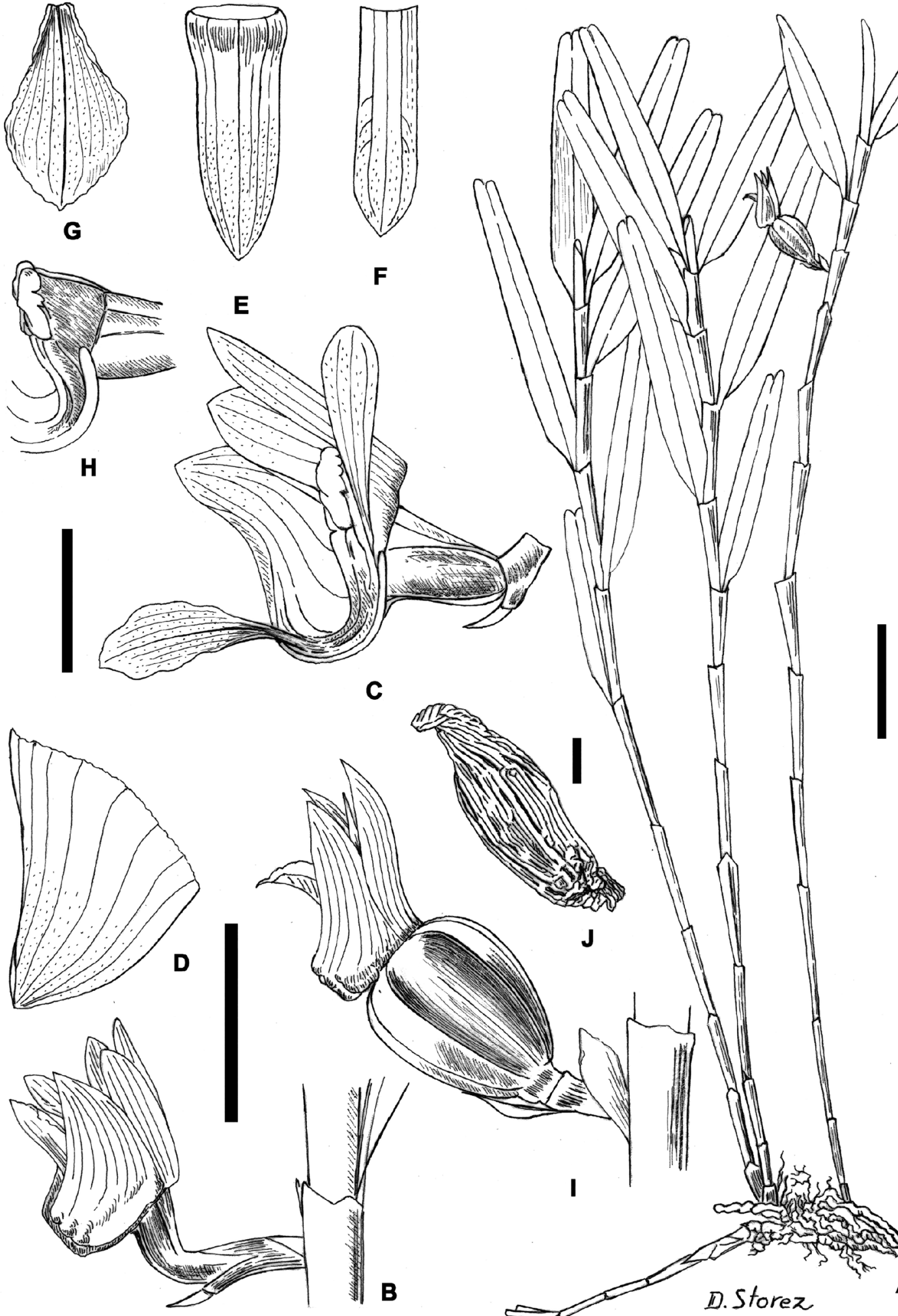


\section{Type material}

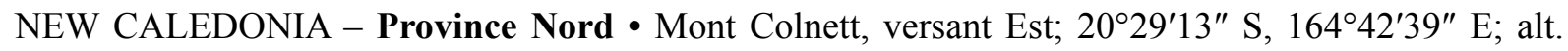
$700 \mathrm{~m}$; border zone between the altitude rainforest and the savanna of burns, schists; 3 Nov. 2003; fl. \& fr.; Mouly 99; holotype: P[P00777176]!; isotypes: P[P00777177]!, NOU[NOU090448!]. - Dendrobium crassifomentum Hallé ined. in herb.

\section{Paratypes}

NEW CALEDONIA - Province Nord - Mont Colnett; alt. 720 m; 29 Oct. 2003; fl.; Butin s.n.; P[P00352883] - Mont Colnett; 20 29'17" S, 16442'43" E; alt. 720 m; 10 May 2003; fl.; Butin s.n.; P[P00493892] • Mont Mandjelia, Pouébo, 20²3'51" S, 164³1'57" E; 10 Dec. 2016; C. Laudereau 98; NOU[NOU090376] • Mont Mandjelia, Pouébo, 20²3'51" S, 164³1'57" E; 23 Dec. 2016; C. Laudereau 213; NOU[NOU090375] • Colnett Oua Ina, Pouébo, 20³0'35" S, 16443'56" E; 5 Jan. 2017; C. Laudereau 239; NOU[NOU090374] • Pouébo, Mont Mandjélia; 20²3'51" S, 164³1'57" E; 24 Oct. 2018; C. Laudereau 1155; NOU[NOU090373] - Mont Mandjélia; [20²4'2" S, 164³1'41" E]; 29 Sep.

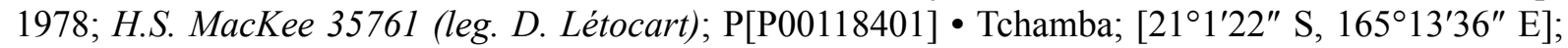
21 Dec. 1978; H.S. MacKee 36261 (leg. D. Létocart); P[P00118403] • Haute Diahot: Tendé; [20²4'28" S, 164³1'17" E]; alt. 700 m; humid forest, micaschists; 12 Dec. 1979; H.S. MacKee 37117; P[P00118404] - Pouébo, Mont Mandjélia; [20²4'2" S, 164³1'41" E]; alt. 750 m; humid forest, schists; 26 Jan. 1980; H.S. MacKee 37760 (leg. Bégaud); P [P00118405] - Pouébo, Mont Mandjélia; [20²4'2" S, 164³1'41" E]; alt. 750 m; 14 Mar. 1980; H.S. MacKee 37908 (leg. D. Létocart); P[P00118402] • ibid.; 20 Dec. 1980; H.S. MacKee 38198 (leg. D. Létocart); P[P00118406] - Roches Ouaième; alt. 950 m; 14 Jun. 2005, J. Munzinger 2915, Y. Pillon \& J.-P. Butin; NOU[NOU007988] • Mandjélia; 2 Dec. 2006; bt. fr.; J. Munzinger 4016, D. Létocart, I. Létocart, R. Amice \& O. Chapelle; NOU[NOU017301]• Mont

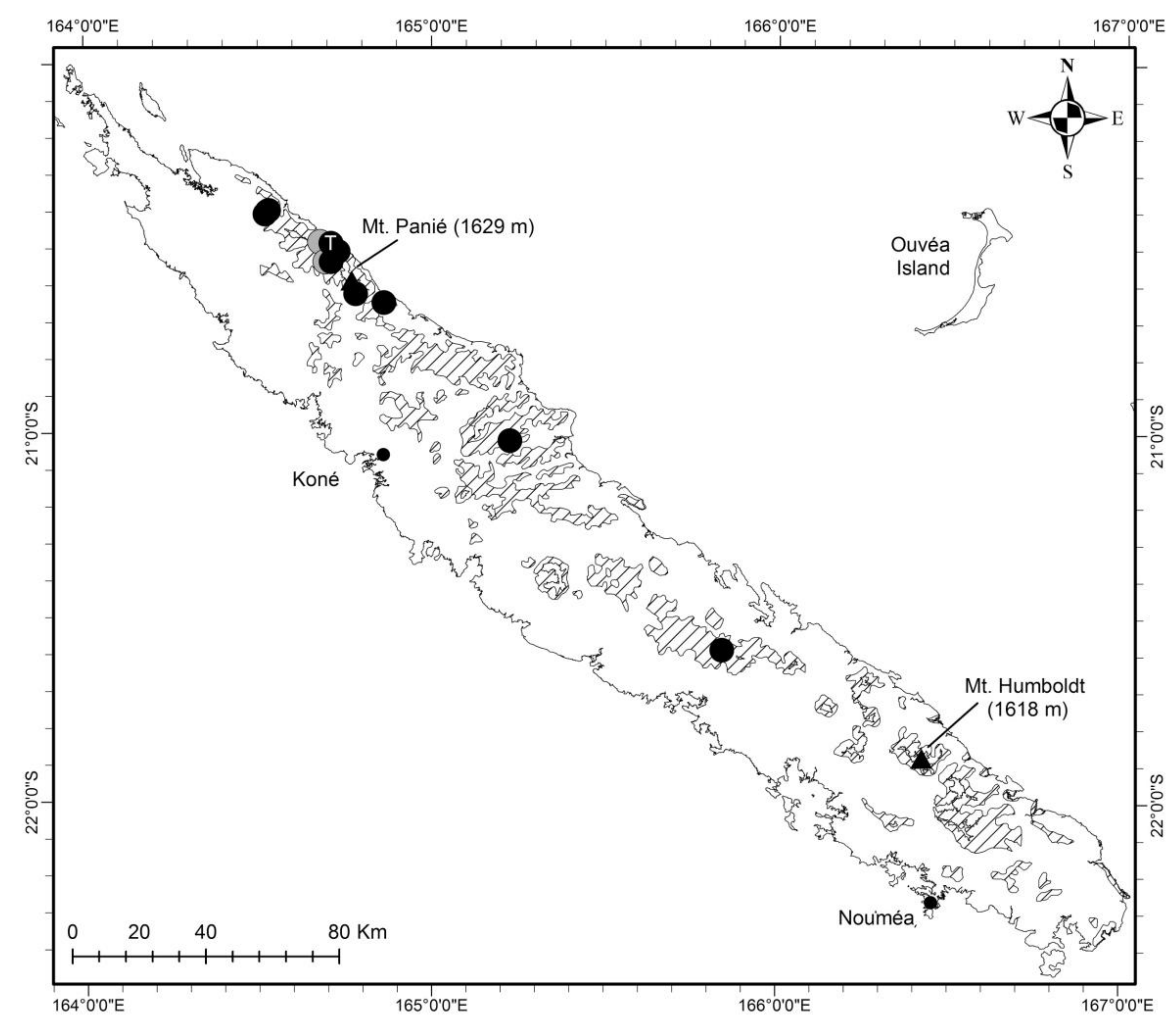

Fig. 11. Distribution of D. letocartiorum Munzinger \& M.Pignal sp. nov., based on herbarium specimens (O) and field observations $(\bigcirc)$, ' $\mathrm{T}$ ' indicates the type collection. 
Panié; [2037'27" S, 16446'56" E]; J. Munzinger 4326, H. Blaffart, M. Wanguene, O. Chapelle \& J. Tiavouane; NOU[NOU018878] - Dawenia, west buttress of Colnett; 20³2'15" S, 164 41'39" E; 14 Nov. 2010; J. Munzinger 6290, Ph. Birnbaum, M. Callmander, I. Pounds, J.-P. Butin \& H. Vandrot; NOU[NOU063469]. - Province Sud • Col d'Amieu: Mt. Pembai; [2135'20" S, 16550'30" E]; alt. 800 m; humid forest, schists; 15 Apr. 1976; fr.; H.S. MacKee 31229 (leg. Bégaud); P[P00118400].

\section{Description}

Erect epiphyte. Roots whitish, ca 1-2 mm wide, at the base of the plant (axillary roots lacking). Stems reaching $60 \mathrm{~cm}$ long, slightly flattened, completely covered by the sheaths of the old leaves, lamina remaining only in the upper half, yellow-orange on dry material. Internodes ca $25 \mathrm{~mm}$ long at the base of the stem. Leaves spirally arranged, dark shiny green above, light green below (fide collectors' notes), ca $75 \times 7 \mathrm{~mm}$. Midrib impressed on adaxial surface, very prominent on abaxial surface. Two lateral nerves very conspicuous, $<1-2 \mathrm{~mm}$ from the margin (see discussion of anatomy below), numerous prominent smaller nerves visible, all convergent at the apex. Base narrow, forming a flattened pseudopetiole. Extremity emarginate, asymmetrical, the two lobes often diverging. Sheath striated in its upper half and ending in a beak opposite to the lamina and applied on the stem. Inflorescence 1-flowered, emerging through a slit of the foliar sheath. Pedicel $3.5 \mathrm{~mm}$ long. Ovary ca $3 \mathrm{~mm}$ long, non-resupinate. Bract acuminate, $2-3 \mathrm{~mm}$ long. Flower pale green to yellow, ca $12 \mathrm{~mm}$ long. Dorsal sepal triangular, $12 \times 2 \mathrm{~mm}$. Lateral sepals triangular, $12 \times 4 \mathrm{~mm}$ at the base, with 7 nerves. Petals linear or slightly lanceolate, $11 \times$ ca $1 \mathrm{~mm}$. Lip entire, red, approximately elliptic, margin thin and undulate, $10 \mathrm{~mm}$ long and $3 \mathrm{~mm}$ wide, obscurely tricarinated. Mentum, $3 \mathrm{~mm}$ long. Column, $2.5 \mathrm{~mm}$ high and $2 \mathrm{~mm}$ wide with a fimbriate margin. Fruits very few despite an abundant flowering, yellow-greenish to brown when mature, ovoid, $8 \mathrm{~mm}$ in diameter, with base slightly narrower. Bracts persistent. Dried seed with transparent testa, ca $267 \times 86 \mu \mathrm{m}$, fusiform, with extremity slender and base truncate, extremity strongly spiraled. Hydrated seed ovate, sacciform. Cells cubic or with extremities rounded, elongate, ca 43-110 $\times 7.3-10.2 \mu \mathrm{m}$, with thick edges, spiral orientation and smooth cellular walls. Embryo spherical elongate, ca $6-7 \mu \mathrm{m}$ wide, inserted in the lower $2 / 3$ of the testa.

\section{Taxonomic notes}

Dendrobium letocartiorum sp. nov. has always slightly flattened stems. The species has affinities with D. bilobum Lindl., but the flower is bigger and the lip does not have a dark red spot on the adaxial surface. Leaf anatomy shows that $D$. letocartiorum sp. nov. is very similar to $D$. camaridiorum, having thin leaves, 24-28 vascular bundles in one line and largest bundle in position 5(-6). They only differ by the margins in transverse section, which are obtuse in $D$. letocartiorum sp. nov. and truncate in D. camaridiorum (Fig. 4B).

\section{Phenology}

Flowering and fructification periods need further observations. The fruits were observed in the field and in cultivation (in New Caledonia) during the months of January, May, July, October, November and December and flowering specimens are from May and November.

\section{Distribution and ecology}

This endemic species occurs on the main island, in the central chain and on the Panié range in North-East coast. It grows on edges of humid forest, and also on rocks as a lithophyte and is known from 700-800 m a.s.l. The species has been observed also in Plateau de Dogny (Sarraméa) (C. Laudereau, pers. comm.) 
Table 1. Anatomical features of graminoid New Caledonian Dendrobium Sw. Ratio BVL / L: ratio of the diameter of the largest vascular bundle / width of the lamina. Stomata types (I \& II) follow the definitions in Yukawa et al. (1992).

\begin{tabular}{llllll}
\hline Dendrobium & $\begin{array}{l}\text { butinii } \\
\text { sp. nov. }\end{array}$ & crassifolium & camaridiorum & $\begin{array}{l}\text { letocartiorum } \\
\text { sp. nov. }\end{array}$ & unicarinatum \\
\hline $\begin{array}{l}\text { Number of } \\
\text { vascular bundles }\end{array}$ & $14-15$ & 33 & $27-29$ & $27-29$ & 15 \\
$\begin{array}{l}\text { Vascular } \\
\text { bundles alignment }\end{array}$ & One line & Two lines & One line & One line & One line \\
$\begin{array}{l}\text { Position of the } \\
\text { largest vascular bundle }\end{array}$ & $3(-4)$ & 6 & $(4-5-) 6$ & $(5-) 6$ & 2 \\
$\begin{array}{l}\text { Ratio BVB/L } \\
\text { Fibre bundles }\end{array}$ & $\begin{array}{l}\text { Few on } \\
\text { abaxial }\end{array}$ & None & None & $\begin{array}{l}\text { Few on } \\
\text { abaxial }\end{array}$ & $\begin{array}{l}\text { Numerous on } \\
\text { both faces }\end{array}$ \\
$\begin{array}{l}\text { Midrib in } \\
\text { transverse section }\end{array}$ & $\begin{array}{l}\text { Not } \\
\text { prominent }\end{array}$ & $\begin{array}{l}\text { Not } \\
\text { prominent }\end{array}$ & Prominent & Prominent & Prominent \\
$\begin{array}{l}\text { Marge in } \\
\text { transverse section }\end{array}$ & $\begin{array}{l}\text { Rounded } \\
\text { or acute }\end{array}$ & Acute & Truncate & Acute & Acute \\
Sype I \& II & Type I \& II & Type I & Type II & Type II \\
\hline
\end{tabular}

\section{IUCN status}

This species is currently known from only four locations in New Caledonia, based on herbarium specimens. Dendrobium letocartiorum sp. nov. was evaluated as Near Threatened (NT) by the New Caledonian Red List Authority, considering the species apparent rarity and the low threat to its habitat.

\section{Anatomical characters}

Analysis of the leaf sections of the five species discussed in the present paper shows that they present strong differences between samples, especially regarding the number of vascular bundles (VB). We assigned a number to each VB, starting from the margin of the lamina (Fig. 4), and observed that the position of the larger VBs is stable and has a diagnostic value for the species, as has the ratio of the size of the larger VBs compared to the thickness of the lamina. Vascular bundles exhibit little variation within a species but can be very different between species. Differences were also seen in the alignment of the VBs, which are in two lines in D. crassifolium, but in only one line in all other species studied. Differences were also observed in the size of VBs number 2 of $D$. crassifolium which are symmetrically situated on each side of the lamina and are larger than the others. The presence of fibre bundles was also a remarkable character, especially in D. unicarinatum. Table 1 summarizes these anatomical characters for each species, which were also used to prepare an identification key to distinguish sterile material of graminoid Grastidineae species from New Caledonia.

\section{Key based on leaf anatomy (transverse section) to the graminoid species of Dendrobium in New Caledonia}

1. Leaves thick, vascular bundles in two parallel lines, very numerous ( $>32)$, largest with diameter $<1 / 2$ the thickness of the leaf blade

- Leaves thin, vascular bundles in one line, less numerous $(<30)$, largest with diameter $>3 / 4$ the thickness of the leaf blade 
2. Vascular bundles $<15$, midrib prominent or not, largest bundles in position 2 or $3(-4-5) \ldots \ldots \ldots \ldots . . .3$

- Vascular bundles $>22$, midrib prominent, largest bundle in position 5(-6) .................................... 4

3. Supernumerary fibre bundles numerous on both sides (>35), large (Fig. 4A), largest vascular bundle in position 2, midrib prominent in leaf section

D. unicarinatum Kores

- Supernumerary fibre bundles only on abaxial side, few $(<15)$, small, largest vascular bundle in position 3(-4-5), midrib not prominent in leaf section

D. butinii M.Pignal \& Munzinger sp. nov.

4. Margins obtuse in transverse section (Fig. 4Ba)

D. letocartiorum Munzinger \& M.Pignal sp. nov.

- Margins truncate in transverse section (Fig. 4Bb)

D. camaridiorum Rchb.f.

\section{Discussion}

The group of graminoid Dendrobium is taxonomically artificial, because it includes species of two sections, Grastidium and Biloba, which do not seem to be phylogenetically related. However, species in this group are characterized by a morphological resemblance and share ecological constants. It is not uncommon for several species of them to meet in the field on the same porophyte.

\section{Dendrobium unicarinatum}

While preparing his treatment of Orchidaceae for the Flore de Nouvelle-Calédonie, Hallé (1977) identified two new taxa in Paris's herbarium, but the material was too poor to enable a complete description. Over the last several years, additional material has become available and careful comparison with collections from the Pacific Islands together with the precise descriptions in the Flora Vitiensis Novae (Kores 1991) show that a part of the material represents a species previously known from Fiji, D. unicarinatum. The other part of the material corresponds to the new taxon D. letocartiorum sp. nov. Dendrobium unicarinatum was included by Kores (1989) in sect. Monanthos, although he mentioned its vegetative resemblances with members of sect. Grastidium, especially D. carnicarinum Kores (1989: 92). While some minor macromorphological differences can be observed (such as apex of the blade and sheath extremity), we doubt they are taxonomically significant. In fact, D. unicarinatum has the same type of sessile inflorescence sheath found in species of sect. Grastidium. On the other hand, several important differences in floral characters can be seen. For example, D. unicarinatum has solitary nonresupinate flowers with an entire lip, while sect. Grastidium is characterised by consistently 2-flowered inflorescences, resupinate flowers, and a trilobate and often fimbriate lip.

Morris et al. (1996) gave anatomical features that characterize Grastidium and Bilobum (which he considered as sections of the former Dendrobium subg. Xerobium Schltr. (Schlechter 1914: 242, 249)), in particular the absence of fibre bundles and a homogeneously seriate leaf margin in Grastidium vs the presence of bundles on both adaxial and abaxial surfaces and heterogeneous seriation in Biloba. We have noted the presence of fibre bundles on both surfaces in the leaves of $D$. unicarinatum, which suggest a placement in sect. Biloba rather than in sect. Grastidium. In D. butinii sp. nov. and D. letocartiorum sp. nov. (the latter species included in sect. Biloba on the basis of floral characters), we found leaf fibre bundles only on the adaxial surface. All five species studied here showed homogeneous seriation. Our observations suggest that these two characters are in fact of limited taxonomic value, and that the importance attached to them by Morris et al. (1996), whose observations were based on only one species for each section, is not justified.

Yukawa et al. (1992) identified two types of stomata in Dendrobium, a Type I, elliptical in shape with a slit-like opening and gradually sloping slides; and a Type II, circular in shape with a round to spindleshape opening and steep sides. Based on their sample, these authors found all sections of Dendrobium 
to have one or the other type of stomata, except Grastidium, which exhibited both types. Members of sect. Biloba were reported to have Type II stomates, and our observations of D. unicarinatum and D. letocartiorum sp. nov. agree with these results (Fig. 5G-H). Our study also confirms the presence of both types within Grastidium, with Type I stomata in D. camaridiorum (Fig. 5A-B), and the surprising presence of both types of stomata in D. crassifolium and D. butinii sp. nov. (see Fig. 5C-F).

Molecular phylogenies based on chloroplast DNA restriction site analysis (Yukawa et al. 1993) and $r b c$ L sequence data (Yukawa et al. 1996) have shown Dendrobium to be para- or polyphyletic, and have pointed out the need of further investigations to clarify systematic relationships among Dendrobiinae Pfitzer (Pfitzer 1889; Pridgeon et al., 2014). Results from an analysis of the Internal Transcribed Spacers (ITS) led Clements (2003) to propose the sub-tribe Grastidiinae which includes most of the species considered by Hallé (1977) as belonging to Dendrobium, Ephemerantha P.F.Hunt \& Summerh. (Hunt \& Summerhayes 1961: 102), Cadetia Gaudich. (in Freycinet 1826-1829: 422, t. 33) and Diplocaulobium Kraenzl. (Kränzlin 1910: 331).

These proposals were rejected in Pridgeon et al. (2014) and would have brought the total number of genera in New Caledonia to 13, an excessive number considering the relatively small differences between the taxa. In line with the international consensus view of a broad concept of Dendrobium (Adams 2011; Schuiteman 2011; Chase et al. 2015; Pridgeon et al. 2014) we have classified all taxa in this paper under Dendrobium.

\section{Acknowledgements}

We particularly wish to thank the late Gérard G. Aymonin and Jacques Florence for corrections of the Latin diagnosis, Pete Lowry for scientific points of view and English corrections and Djane Vasconcelos for the final English review. We are also indebted to the late Elisabeth Lopez (Service des cultures, MNHN), and the late Pierre Poulain (Parc E. Liais, Cherbourg-en-Cotentin), who provided living material and helped with growing plants. Scanning electron microscope pictures were taken at the 'Service de microscopie électronique du MNHN'. Thanks to Daniel and Irène Létocart, Jean-Pierre Butin, Christian Laudereau, David Bruy, Arnaud Mouly and Gordon McPherson for help in the field, sharing observations or providing material, and to all collectors cited in the studied material. IRD and MNHN gave access to the collections in the framework of the RECOLNAT National Research Infrastructure (ANR-11INBS-0004). Thanks to the New Caledonian Red List Authority, especially Christian Laudereau for his precise phenological observations and the Endemia association, especially Shankar Meyer, for sharing data and IUCN status assessments. The authors warmly thank the two anonymous reviewers whose proposals have greatly improved the manuscript.

\section{References}

Adams P.B. 2011. Systematics of Dendrobiinae (Orchidaceae), with special reference to Australian taxa. Botanical Journal of the Linnean Society 166: 105-126.

https://doi.org/10.1111/j.1095-8339.2011.01141.x

Carlsward B.S., Stern W.L., Judd W.S. \& Lucansky T.W. 1997. Comparative leaf anatomy and systematics in Dendrobium, sections Aporum and Rhizobium (Orchidaceae). International Journal of Plant Sciences 158: 332-342. https://doi.org/10.1086/297445

Chase M.W., Cameron K.M., Freudenstein J.V., Pridgeon A.M., Salazar G.A., Van den Berg C. \& Schuiteman A. 2015. An updated classification of Orchidaceae. Botanical Journal of the Linnean Society 177: 151-174. https://doi.org/10.1111/boj.12234 
Clements M.A. 2003. Molecular phylogenetic systematics in the Dendrobiinae (Orchidaceae), with emphasis on Dendrobium section Pedilonum. Telopea 10: 247-298.

https://doi.org/10.7751/telopea20035619

Faria E. 2016. Diversité du genre Corybas Salisb. (Orchidaceae, Diurideae) en Nouvelle-Calédonie. Adansonia sér. 3 38: 175-198. https://doi.org/10.5252/a2016n2a4

Freycinet L.D. 1826-1829. Voyage autour du Monde, exécuté sur les corvettes de SM l'Uranie et la Physicienne, etc. Navigation et Hydrographie, première partie, et Atlas. Pillet Aîné, Paris.

Gâteblé G., Barrabé L., McPherson G., Munzinger J., Snow N. \& Swenson U. 2018. One new endemic plant species on average per month in New Caledonia, including eight more new species from Ile Art (Belep Islands), a major micro-hotspot in need of protection. Australian Systematic Botany 31: 448-480. https://doi.org/10.1071/SB18016

Hallé N. 1977. Orchidacées. In: Aubréville A. \& Leroy J.-F. (eds) Flore de la Nouvelle-Calédonie et Dépendances: 1-565. Muséum national d'histoire naturelle, Paris.

Hunt P.F. \& Summerhayes V.S. 1961. Notes on Asiatic Orchids III. Taxon 10: 101-110. https://doi.org/10.2307/1217855

Kores P.J. 1989. A precursory study of Fijian Orchids. Allertonia 5: 1-222.

Available from https://www.jstor.org/stable/23188211 [accessed 15 Apr. 2020].

Kores P.J. 1991. Orchidaceae. In: Smith A.C. (ed.) Flora Vitiensis Nova: a New Flora of Fiji (spermatophyte only): 321-576. National Tropical Botanical Garden, Lawai, Kauai, Hawaii.

Kränzlin F.W. 1894. Orchidacea Papuanae. Österreichische Botanische Zeitschrift 44: 333-338. https://doi.org/10.1007/BF01794849

Kränzlin F.W. 1910. Orchidaceae-Monandrae-Dendrobiinae. Pars. 1. In: EnglerA.(ed.) Das Pflanzenreich Regni vegetabilis conspectus: 1-331. Engelmann, Leipzig.

Kränzlin F.W. 1914. Orchidaceae von Neu-Caledonien und den Loyalty-Inseln. In: Sarazin F. \& Roux J. (eds) Nova Caledonia: 84. Kreidel's Verlag, Berlin \& Wiesbaden.

Lowry II P.P. 1998. Diversity, endemism, and extinction in the Flora of New Caledonia: a review. In: Peng C.-I. \& Lowry II P.P. (eds) Rare, Threatened, and Endangered Floras of Asia and the Pacific: 181-206. Institute of Botany, Academica Sinica, Monogr. Ser. No. 16, Taipei.

Morat P. 1993. Our knowledge of the flora of New Caledonia: endemism and diversity in relation to vegetation types and substrates. Biodiversity Letters 1: 72-81. https://doi.org/10.2307/2999750

Morat P. 2010. Les botanistes récolteurs en Nouvelle-Calédonie de 1774 à 2005. Adansonia, sér. 3 32: 159-216. https://doi.org/10.5252/a2010n2a1

Morat P., Jaffré T., Tronchet F., Munzinger J., Pillon Y., Veillon J.-M. \& Chalopin M. 2012. Le référentiel taxonomique Florical et les caractéristiques de la flore vasculaire indigène de la Nouvelle-Calédonie. Adansonia sér. 3 34: 177-219. https://doi.org/10.5252/a2012n2a1

Morris M.W., Stern W.L. \& Judd W.S. 1996. Vegetative anatomy and systematics of subtribe Dendrobiinae (Orchidaceae). Botanical Journal of the Linnean Society 120: 89-144.

https://doi.org/10.1111/j.1095-8339.1996.tb00483.x

Pfitzer E. 1889. Orchidaceae. In: Engler A. \& Prantl K. (eds) Die natürlichen Pflanzenfamilien nebst ihren Gattungen und wichtigeren Arten, II.6: 52-218. Engelmann, Leipzig. 
Pierre A.-H., Le Moguédec G., Lowry II P.P. \& Munzinger J. 2014. Multivariate morphometric analysis and species delimitation in the endemic New Caledonian genus Storthocalyx (Sapindaceae). Botanical Journal of the Linnean Society 176: 127-146. https://doi.org/10.1111/boj.12199

Pignal M. \& Munzinger J. 2011. Une nouvelle espèce de Microtatorchis (Orchidaceae, Vandeae, Aeridinae) en Nouvelle-Calédonie, et une clef d'identification pour les Aeridinae aphylles du territoire. Adansonia sér. 3 33: 183-190. https://doi.org/10.5252/a2011n2a2

Pouteau R., Trueba S., Feild T. \& Isnard S. 2015. New Caledonia: A Pleistocene refugium for rainforest lineages of relict angiosperms. Journal of Biogeography 11:2062-2077.https://doi.org/10.1111/jbi.12581

Pridgeon A.M., Cribb P.J., Chase M.W. \& Rasmussen F.N. 2014. Genera orchidacearum, Vol. 6. Oxford University Press, Oxford.

Rauschert S. 1983. Beitrag zur Nomenklatur der Orchidaceae. Feddes Repertorium. Zeitschrift für Botanische Taxonomie und Geobotanik 94: 433-471.

Reichenbach H.G. 1876. Orchidiographische Beiträge. Linnaea 41(1): 17-98.

Available from https://www.biodiversitylibrary.org/page/123722\#page/18/mode/1up [accessed 15 Apr. 2020]

Schlechter R. 1906. Beiträge zur Kenntnis der Flora von Neu-Kaledonien. Botanische Jahrbücher für Systematik, Pflanzengeschichte und Pflanzengeographie 39(1): 1-274.

Available from https://www.biodiversitylibrary.org/page/213837\#page/1 [accessed 15 Apr. 2020].

Schlechter R. 1912. XXXIX. Orchidaceae novae et criticae. Repertorium Specierum Novarum Regni Vegetabilis, Beihefte 1: 248-254.

Schlechter R. 1914. Die orchidaceen von Deutsch-Neu-Guinea. Repertorium Specierum Novarum Regni Vegetabilis, Beihefte 1.

Available from https://www.biodiversitylibrary.org/item/28953\#page/6/mode/1up [accessed 15 Apr. 2020].

Schuiteman A. 2011. Dendrobium (Orchidaceae): To split or not to split? Gardens'Bulletin Singapore 63: 245-257.

Available from https://www.biodiversitylibrary.org/page/43627168 [accessed 15 Apr. 2020].

Smith J.J. 1905a. Die Orchideen von Java. In: Brill E.J. (ed.) Flora von Buitenzorg. Leiden. https://doi.org/10.5962/bhl.title.86938

Smith J.J. 1905b. Die orchideen von Ambon. Landsdrukkerij. https://doi.org/10.5962/bhl.title.86926

Smith J.J. 1908. Vorläufige Beschreibungen neuer papuanischer Orchideen. Bulletin du Département de l'Agriculture aux Indes Néerlandaises. Buitenzorg 19: 1-39.

Stern W.L., Morris M.W. \& Judd W.S. 1994. Anatomy of the thick leaves in Dendrobium section Rhizobium (Orchidaceae). International Journal of Plant Sciences 155: 716-729.

https://doi.org/10.1086/297210

Thiers B. Continuously updated. Index Herbariorum: A global directory of public herbaria and associated staff. New York Botanical Garden's Virtual Herbarium.

Available from http://sweetgum.nybg.org/science/ih/ [accessed 15 Apr. 2020].

Turland N.J., Wiersema J.H., Barrie F.R., Greuter W., Hawksworth D.L., Herendeen P.S., Knapp S., Kusber W.-H., Li D.-Z., Marhold K., May T.W., McNeill J., Monro A.M., Prado J., Price M.J. \& Smith G.F. (eds). 2018. International Code of Nomenclature for algae, fungi, and plants (Shenzhen Code) adopted by the Nineteenth International Botanical Congress Shenzhen, China, July 2017. Koeltz Botanical Books, Glashütten. 
Yukawa T. \& Uehara K. 1996. Vegetative diversification and radiation in subtribe Dendrobiinae (Orchidaceae): evidence from chloroplast DNA phylogeny and anatomical characters. Plant Systematics and Evolution 201: 1-14. https://doi.org/10.1007/BF00989048

Yukawa T., Ando T., Karasawa K. \& Hashimoto K. 1992. Existence of two stomatal shapes in the genus Dendrobium (Orchidaceae) and its systematic significance. American Journal of Botany 79: 946-952. https://doi.org/10.2307/2445006

Yukawa T., Kurita S., Nishida M. \& Hasebe M. 1993. Phylogenetic implications of chloroplast DNA restriction site variation in subtribe Dendrobiinae (Orchidaceae). Lindleyana 8: 211-221.

Yukawa T., Ohba H., Cameron K. \& Chase M. 1996. Chloroplast DNA phylogeny of subtribe Dendrobiinae (Orchidaceae): insights from a combined analysis based on rbcL sequences and restriction site variation. Journal of Plant Research 109: 169-176. https://doi.org/10.1007/BF02344542

Manuscript received: 12 September 2019

Manuscript accepted: 3 December 2019

Published on: 23 April 2020

Topic editor: Frederik Leliaert

Editor-in-Chief: Koen Martens

Desk editor: Connie Baak

Printed versions of all papers are also deposited in the libraries of the institutes that are members of the EJT consortium: Muséum national d'histoire naturelle, Paris, France; Meise Botanic Garden, Belgium; Royal Museum for Central Africa, Tervuren, Belgium; Royal Belgian Institute of Natural Sciences, Brussels, Belgium; Natural History Museum of Denmark, Copenhagen, Denmark; Naturalis Biodiversity Center, Leiden, the Netherlands; Museo Nacional de Ciencias Naturales-CSIC, Madrid, Spain; Real Jardín Botánico de Madrid CSIC, Spain; Zoological Research Museum Alexander Koenig, Bonn, Germany; National Museum, Prague, Czech Republic. 